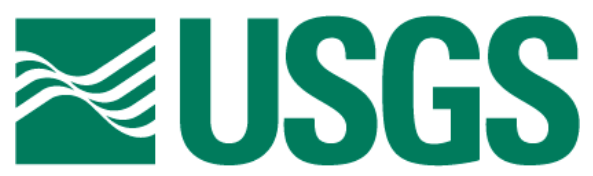

science for a changing world

\title{
Preliminary Analytical Results for a Mud Sample Collected from the LUSI Mud Volcano, Sidoarjo, East Java, Indonesia
}

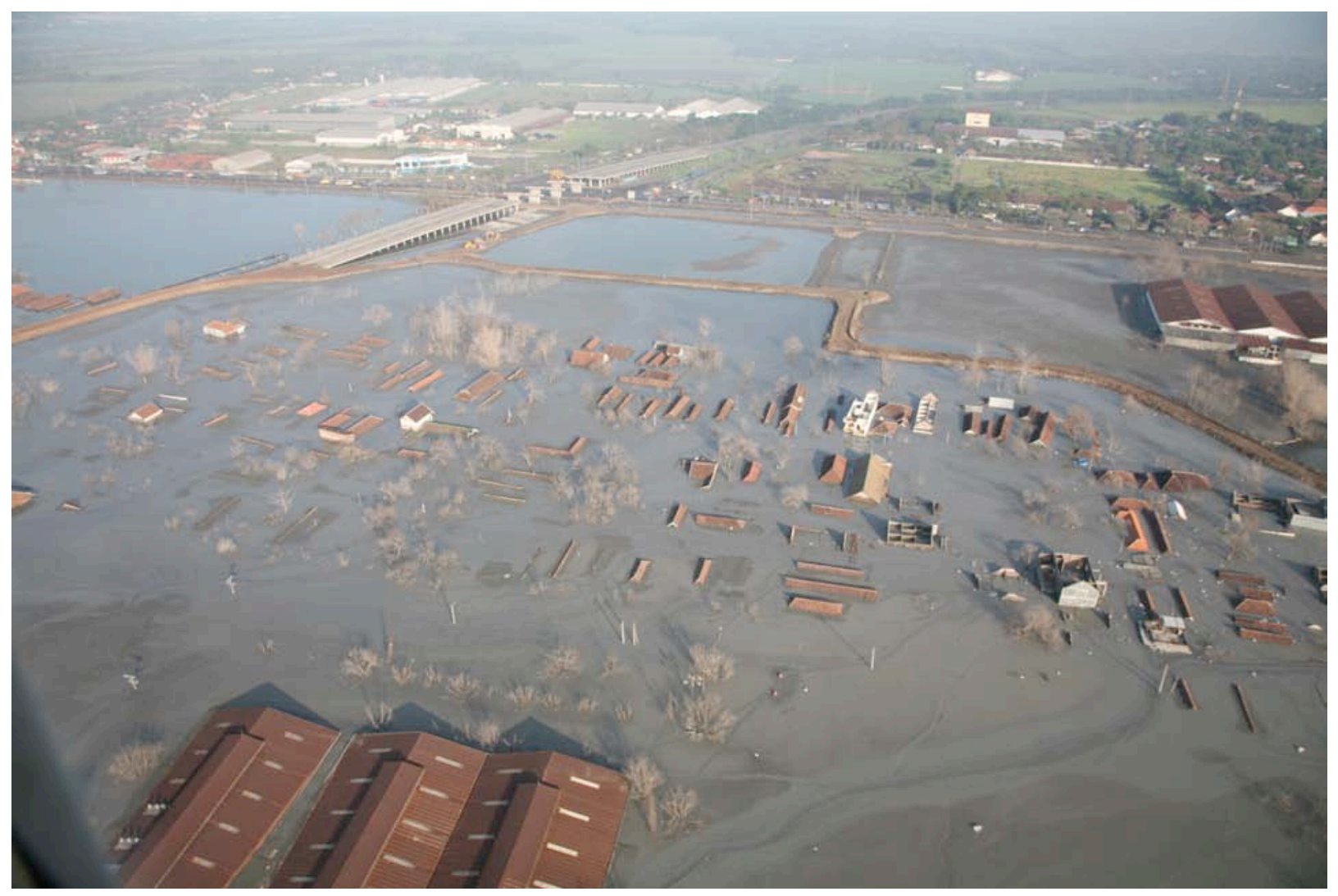

By Geoffrey S. Plumlee, Thomas J. Casadevall, Handoko T. Wibowo, Robert J. Rosenbauer, Craig A. Johnson, George N. Breit, Heather A. Lowers, Ruth E. Wolf, Philip L. Hageman, Harland Goldstein, Michael W. Anthony, Cyrus J. Berry, David L. Fey, Gregory P. Meeker, and Suzette A. Morman

Open-File Report 2008-1019

U.S. Department of the Interior

U.S. Geological Survey 


\section{U.S. Department of the Interior \\ DIRK KEMPTHORNE, Secretary}

\section{U.S. Geological Survey \\ Mark D. Myers, Director}

U.S. Geological Survey, Reston, Virginia 2008

For product and ordering information:

World Wide Web: http://www.usgs.gov/pubprod

Telephone: 1-888-ASK-USGS

For more information on the USGS - the Federal source for science about the Earth, its natural and living resources, natural hazards, and the environment:

World Wide Web: http://www.usgs.gov

Telephone: 1-888-ASK-USGS

Suggested citation:

Plumlee, G.S., Casadevall, T.J., Wibowo, H.T., Rosenbauer, R.J., Johnson, C.A., Breit, G.N., Lowers, H.A., Wolf, R.E., Hageman, P.L., Goldstein, H., Anthony, M.W., Berry, C.J., Fey, D.L.,, Meeker, G.P., and Morman, S.A., 2008, Preliminary analytical results for a mud sample collected from the LUSI mud volcano, Sidoarjo, East Java, Indonesia: U.S. Geological Survey Open-File Report 2008-1019.

Any use of trade, product, or firm names is for descriptive purposes only and does not imply endorsement by the U.S. Government.

Although this report is in the public domain, permission must be secured from the individual copyright owners to reproduce any copyrighted material contained within this report.

Cover photo by Handoko T. Wibowo, Sidoarjo Mud Flow Mitigation Agency. See description on Figure 4 caption. 


\section{Contents}

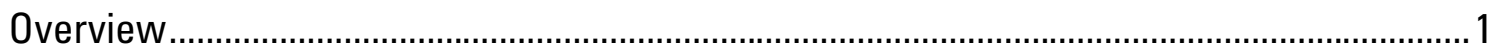

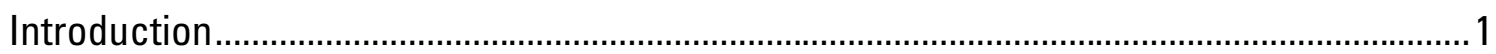

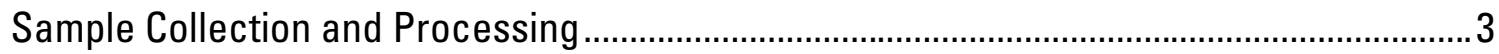

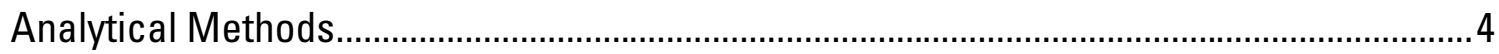

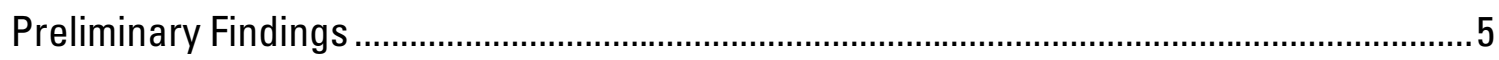

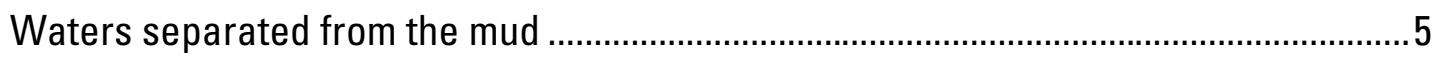

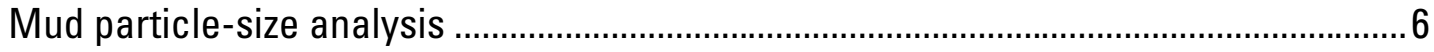

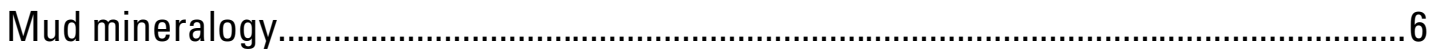

Mud inorganic chemical composition......................................................................

Mud organic chemical composition .............................................................................

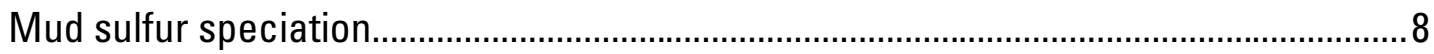

Net acid-production potential................................................................................

Insights from the Mud and Water Analytical Results ……...............................................

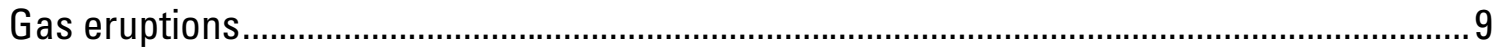

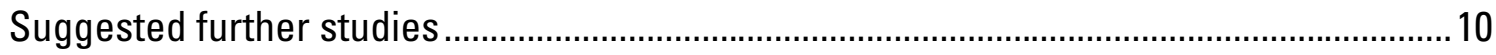

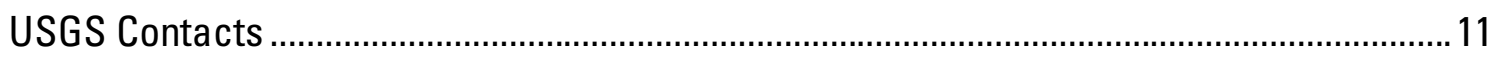

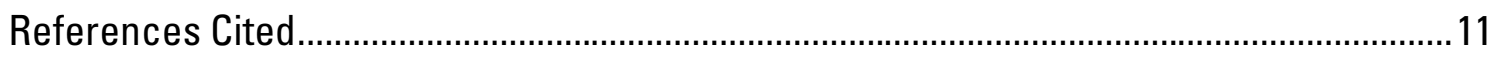

\section{Table}

1. Preliminary analytical results for water separated from LUSI mud ............................... 15

2. Preliminary analytical results for the hydrogen and oxygen isotopic composition of

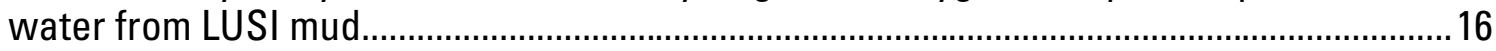

3. Semi-quantitative XRD analytical results on the LUSI mud ...........................................16

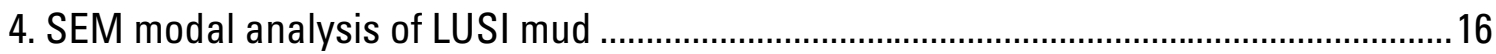

5. Bulk chemical composition of LUSI mud .................................................................. 17

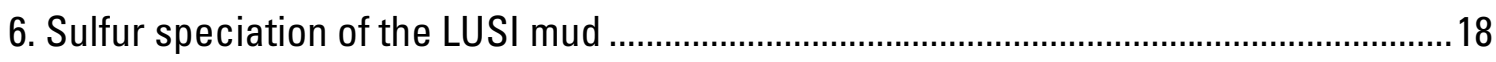

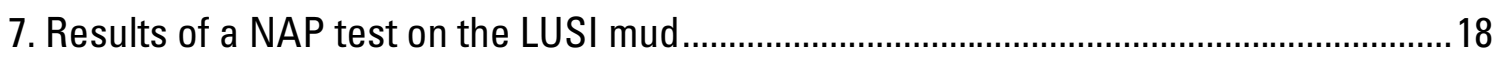

\section{Figure}

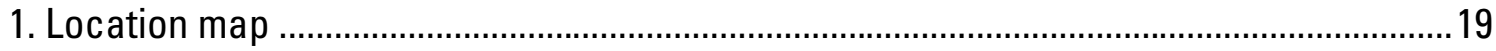

2. January 8,2008 satellite image of the LUSI mud volcano and surrounding area ...........20

3. Oblique aerial photograph of the mud inundation area ...................................................

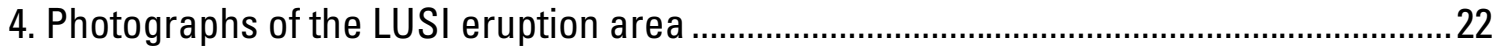

5. Plot, hydrogen and oxygen isotopic composition of water from the LUSI mud ..............23

6. Particle size distribution plot of the LUSI mud.............................................................. 24

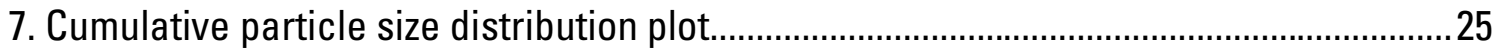

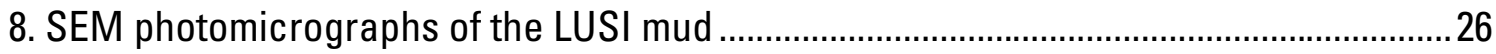




\title{
Preliminary Analytical Results for a Mud Sample Collected from the LUSI Mud Volcano, Sidoarjo, East Java, Indonesia
}

\author{
By Geoffrey S. Plumlee, ${ }^{1}$ Thomas J. Casadevall, ${ }^{1}$ Handoko T. Wibowo, ${ }^{2}$ \\ Robert J. Rosenbauer, ${ }^{1}$ Craig A. Johnson, ${ }^{1}$ George N. Breit, ${ }^{1}$ Heather A. \\ Lowers, ${ }^{1}$ Ruth E. Wolf, ${ }^{1}$ Philip L. Hageman, ${ }^{1}$ Harland Goldstein, ${ }^{1}$ Michael W. \\ Anthony, ${ }^{1}$ Cyrus J. Berry, ${ }^{1}$ David L. Fey, ${ }^{1}$ Gregory P. Meeker, ${ }^{1}$ and Suzette A. \\ Morman $^{1}$ \\ ${ }^{1}$ U.S. Geological Survey \\ ${ }^{2}$ Sidoarjo Mudflow Mitigation Agency
}

\section{Overview}

On May 29, 2006, mud and gases began erupting unexpectedly from a vent 150 meters away from a hydrocarbon exploration well near Sidoarjo, East Java, Indonesia. The eruption, called the LUSI (Lumpur "mud"-Sidoarjo) mud volcano, has continued since then at rates as high as $160,000 \mathrm{~m}^{3}$ per day. At the request of the United States Department of State, the U.S. Geological Survey (USGS) has been providing technical assistance to the Indonesian Government on the geological and geochemical aspects of the mud eruption. This assistance included a site visit in September 2007 by USGS Central Regional Director Thomas J. Casadevall, who collected a sample of the LUSI mud on September 22, 2007. This report presents initial characterization results of that mud sample, as well as interpretive findings based on the analytical results. The focus is on characteristics of the mud sample (including the solid and water components of the mud) that may be of potential environmental or human health concern. However, characteristics that provide insights into the possible origins of the mud and its contained solids and waters have also been evaluated. The one-liter sample of the mud described here is not representative of the more than 30 million cubic meters of mud erupted to date. As a result, this report also presents recommendations for further studies that are needed to more fully understand potential environmental and health characteristics of the mud, contained waters, and gases as they continue to erupt, and of the mud deposits that have been accumulating since the initial eruption.

\section{Introduction}

On May 29, 2006, mud and gases began erupting unexpectedly from a vent 150 meters away from a hydrocarbon exploration well near Sidoarjo, East Java, Indonesia (fig. 1). The eruption, called the LUSI (Lumpur "mud"-Sidoarjo) mud volcano, has continued since then at rates as high as $160,000 \mathrm{~m}^{3}$ per day. Overviews of the LUSI site and history of eruption have been provided by Davies and others (2008b), Marshall 
(2008), Mazzini and others (2007), Davies and others (2007), Cyranoski (2007), and United Nations Environment Program/Office for the Coordination of Humanitarian Affairs (2006).

As of the fall of 2007, over 30 million $\mathrm{m}^{3}$ of mud with temperatures ranging from 70 $100^{\circ} \mathrm{C}$ had erupted, and the eruption continues as of June 2008 . The mud has inundated an area in excess of $6.5 \mathrm{~km}^{2}$, in spite of ongoing attempts to contain it via the construction of a series of levees (figs. 2-4) that periodically fail. The mud is erupting primarily from a 60-m wide central crater (fig. 3), and is accumulating behind the levee system. It is also being pumped into the Kali Porong River diversion channel (figs. 3, 4D), which then carries the mud somewhat ineffectively (due to the low gradient) to the ocean approximately $20 \mathrm{~km}$ to the east. Accumulation of mud is also accompanied by considerable subsidence in the area around the main eruption vent; at current eruption rates of $\sim 110,000 \mathrm{~m}^{3} /$ day, it has been projected that more than $30 \mathrm{~m}$ of subsidence will occur in the next several years within several $\mathrm{km}$ of the central eruption crater. There has been considerable debate regarding the triggering mechanism for the eruption, specifically the role of the exploration drilling versus a magnitude 6.3 earthquake on May 26, 2006 at Yogyakarta several hundred kilometers to the west (fig. 1: Davies and others, 2008a; Mazzini and others, 2007; Davies and others, 2007; Manga, 2007). The Mazzini and others (2007) study favors the earthquake mechanism, whereas the other studies favor the drilling as the trigger mechanism.

The mud inundation has caused over 30,000 persons to be displaced from more than a dozen villages in the area (figs. 4A-C). The inundation of numerous factories, farmland, and a major toll road (figs. 2, 3, 4) has caused significant economic impacts on the region. In addition, a water-supply pipeline for the city of Surabaja to the north and a fiber-optic cable are in the area of subsidence and mud inundation. A gas pipeline near the eruption ruptured and exploded, reducing the supply of gas available for local fertilizer production, which has in turn led to local fertilizer shortages.

In late February, 2008, localized natural gas seeps or eruptions began to occur in residential and industrial areas outside the zone of major mud accumulation but within the area of subsidence (Davies and others, 2008a). These seeps and eruptions pose an additional safety threat, as several have explosively combusted when exposed to a flame source such as an electrical spark.

Attempts to staunch the flow of mud have been unsuccessful, and now attention is shifting to the development of a plan for long-term management of the mud. Concerns have been expressed regarding potential adverse impacts of the mud on affected river and marine environments, and on the health of local residents exposed to the wet mud, waters that have contacted the mud, or dusts generated from dried mud deposits. Previous studies that examined the mud have found low levels of potentially toxic heavy metals and organic contaminants (for example, United Nations Environment Program/Office for the Coordination of Humanitarian Affairs, 2006). However, these studies have not examined the full range of characteristics of the mud that may be of potential concern from an environmental or human-health perspective.

The U.S. Department of State (DoS) has been asked by the Government of Indonesia to provide technical assistance on the mud eruption. In June 2007, the DoS contacted the USGS to aid in an assessment of the geological and geochemical aspects of the mud eruption. In late September, 2007, USGS Central Region Director Thomas J. Casadevall 
visited Indonesian government officials in Jakarta for briefings on the issue, and then visited the LUSI eruption site with Handoko T. Wibowo of the Sidoarjo Mud Mitigation Agency and other government officials.

As part of the site visit, a sample of the LUSI mud was collected on September 22, 2007. Logistical constraints precluded collection of samples of previously erupted mud. This report presents initial characterization results of that mud sample, as well as interpretive findings based on the analytical results. The focus is on characteristics of the mud sample (including the solid and water components of the mud) that may be of potential environmental or human health concern. However, characteristics that provide insights into the possible origins of the mud and its contained solids and waters have also been evaluated. The one-liter sample of the mud described here is not representative of the more than 30 million cubic meters of mud erupted to date. Hence, this report also presents recommendations for further studies that are needed to more fully understand potential environmental and health characteristics of the mud, contained waters, and gases as they continue to erupt, and of the mud deposits that have been accumulating since the initial eruption.

This is one in a series of USGS environmental/health characterization studies of materials generated by extreme events, including dusts generated by the World Trade Center collapse (Clark and others, 2001, 2005; Meeker and others, 2005; Plumlee and others, 2005; Swayze and others, 2005), Hurricane Katrina flood sediments (Plumlee and others, 2007a); and ash from the 2007 southern California wildfires (Plumlee and others, 2007b).

\section{Sample Collection and Processing}

The mud sample was collected directly from the central eruption crater by backhoe. Material from the middle of the backhoe bucket was transferred into an empty, clean, commercial plastic drinking-water bottle, which was completely filled and then sealed tightly. Upon return to the United States the bottle was refrigerated until processed for analysis.

After being stored for several days in the refrigerator, the mud had settled in the bottle, leaving clear water occupying the uppermost 20 percent of the bottle. A very small gas bubble (approximately $1 \mathrm{~mm}^{3}$ ) was also present.

Immediately upon opening the bottle, a new sterile, high-density polyethylene (HDPE) syringe was used to extract as much of the headspace water as possible. Samples were collected for the following analyses:

- Dissolved cations and trace metals analysis: The sample was filtered through a $0.45-\mu \mathrm{m}$ syringe filter into an acid-washed HDPE bottle and stabilized with several drops of Ultrex nitic acid.

- Dissolved anions and alkalinity: The sample was filtered through a $0.45-\mu \mathrm{m}$ syringe filter into a deionized water-rinsed HDPE bottle.

- Dissolved organic carbon and qualitative organic analysis: The sample was filtered through a $0.7-\mu \mathrm{m}$ glass-fiber filter in a stainless-steel filter holder into a baked brown glass bottle with Teflon-sealed cap. 
After headspace water was removed, the mud gave off a strong oil smell. The mud was medium gray with a slight greenish tint. A stainless steel spatula was used to scoop mud samples from along the entire length of the sample bottle. An archive split of the mud and a split for organic analysis were each collected into a baked brown glass jar with a Teflon lid and frozen. The remainder of the sample was then freeze-dried. Splits of the freeze-dried sample were processed according to the requirements for each of the different analytical methods applied.

\section{Analytical Methods}

A number of different analytical methods have been applied or are being applied to the LUSI mud and headspace water samples. Details of the methods are mostly described in Taggart (2002), otherwise specific references are listed by the particular technique. Methods include:

- Bulk inorganic chemical composition of the solid-mud component, on a freezedried, ground split using inductively coupled plasma-mass spectrometry (ICPMS) for a 44-element suite. The analysis follows a four-acid digestion of the solid sample; this digestion typically is considered a total digestion of most environmental materials.

- Mercury content of the solid-mud component, analyzed on a freeze-dried, ground split using continuous flow-cold vapor-atomic absorption spectrometry.

- Powder X-ray diffraction analysis of a freeze-dried, ground sample split for mineral identification.

- Particle mineralogy and morphology characterization of a freeze-dried, unground split using scanning electron microscopy (SEM).

- Particle size analysis using a Malvern Mastersizer-S long bed laser analyzer. An un-ground, gently disaggregated, freeze-dried sample was introduced into an aqueous medium and pumped through the laser analyzer for grain size measurements.

- Solid sulfur speciation of an unground, undried mud sample.

- Organic chemical composition of the mud by gas chromatography/mass spectroscopy (GC/MS) following organic extraction by a microwave-assisted solvent extraction system (MARSX, CEM Corp.) (Kvenvolden and others, 2002) and compound fractionation by adsorption chromatography (Kvenvolden and others, 1995).

- Net acid-production test of a ground and micronized freeze-dried mud split (Fey and others, 2000)

- $\mathrm{pH}$, alkalinity, specific conductance, anions by ion chromatography, cations and metals by ICP-MS on the water separated from the mud.

- Dissolved organic carbon (DOC) analysis on the separated water, using a Shimadzu 5000A organic carbon analyzer.

- Stable hydrogen and oxygen isotopic composition of the separated water: hydrogen isotopes measured by zinc reduction (Kendall and Coplen, 1985); oxygen isotopes measured by equilibration with carbon dioxide (Kishima and Sakai, 1980). 


\section{Preliminary Findings}

\section{Waters separated from the mud}

The waters separated from the LUSI mud (table 1) are near neutral ( $\mathrm{pH} 7.42)$, with high dissolved solids (37.8 millisiemen/cm). Inductively coupled plasma-mass spectrometry analysis indicates that sodium is the dominant cation, although concentrations exceed the maximum detection limit of the ICP-MS of $200 \mathrm{mg} / \mathrm{L}$. Lesser amounts of calcium, magnesium, and potassium are present. Anion analysis using ion chromatography and alkalinity analysis by titration indicate that chloride is by far the dominant anion $(14,070 \mathrm{mg} / \mathrm{L})$, with lesser sulfate $(306 \mathrm{mg} / \mathrm{L})$ and alkalinity $(236 \mathrm{mg} / \mathrm{L}$ calcium carbonate), nitrate (169 mg/L) and fluoride $(34 \mathrm{mg} / \mathrm{L})$. Measurements based on triplicate analyses with varying dilution indicate DOC levels are quite high $(220 \mathrm{mg} / \mathrm{L})$, as compared to concentrations less than approximately $20 \mathrm{mg} / \mathrm{L}$ for many fresh river waters.

Of the trace metals and metalloids of potential toxicity concern, arsenic and selenium have quite high concentrations (near 59 and $223 \mu \mathrm{g} / \mathrm{L}$, respectively). However, actual concentrations of these elements may be somewhat lower than measured, because high chloride matrices result in analytical interferences that can lead to overestimation of As and Se by ICP-MS analysis. Although precautions were taken during the analysis and data reduction processes to address these potential interferences, some concentration enhancement for As and Se may remain. Further work is recommended on the water using alternative analytical methods to determine more accurately the concentrations of As and Se, because the concentrations as measured by ICP-MS of these elements in the samples exceed both U.S. Environmental Protection Agency (USEPA) primary drinking water Maximum Contaminant Levels (MCLs: arsenic-10 $\mu \mathrm{g} / \mathrm{L}$, selenium-50 $\mu \mathrm{g} / \mathrm{L}$ ) and USEPA criterion continuous concentrations (CCC) for chronic toxicity to marine aquatic life (arsenic-36 $\mu \mathrm{g} / \mathrm{L}$; selenium-71 $\mu \mathrm{g} / \mathrm{L}$ ) (U.S. Environmental Protection Agency, 2006, 2003).

Of the major species present in the waters, fluoride and nitrate are both present in levels that substantially exceed USEPA MCLs (fluoride-10 mg/L; nitrate- $45 \mathrm{mg} / \mathrm{L}$, recalculated from nitrogen-10 mg/L) for primary drinking water (U.S. Environmental Protection Agency, 2003). Concentrations of a number of constituents in the water also exceed USEPA secondary drinking-water regulations (USEPA, 2003); these include iron, manganese, aluminum, sulfate, chloride, and total dissolved solids (the latter constituent was not measured but is inferred to exceed MCLs based on specific-conductance measurements).

The stable hydrogen and oxygen isotope composition of the waters (table 2) is within the range of compositions published by Mazzini and others (2007) for LUSI mud collected in 2006 (fig. 5). Isotopically, the LUSI waters resemble sedimentary formation waters from other localities (U.S. Gulf coast, Michigan basin), as also noted by Mazzini and others (2007). One interpretation for the origin of "formation waters" is that they are actually meteoric waters (fresh surface waters) that evolved isotopically during diagenesis (the transformation of the enclosing marine sediments into rock). An alternative hypothesis is that these formation waters resulted from mixing of original marine pore waters modified by mixing with meteoric waters during diagenesis. 
The concentrations of dissolved elements and species measured in the water separated from the LUSI muc generally fall within the range of concentrations listed for sedimentary formation brines (Kharaka and Hanor, 2007). Fluoride concentrations in the LUSI water sample are at the high end of the range for sedimentary-formation brines, but are consistent with the noted correlation of high fluoride with high chloride in formation brines (Kharaka and Hanor, 2007). Kharaka and Hanor (2007) do not report concentrations of nitrate in sedimentary formation brines. However, nitrate measured in the LUSI sample may have formed from the oxidation of ammonia in the water following sampling, and the LUSI nitrate concentration is within the range of concentrations that would be yielded by the oxidation of ammonia concentrations listed by Kharaka and Hanor (2007).

\section{Mud particle-size analysis}

Particle-size analysis was performed on a freeze-dried split of the mud. The split was further sub-sampled for duplicate analyses. Sodium hexametaphosphate was added to the subsamples, which were then placed on a shaker table to deflocculate the clays. The subsamples were then placed in an ultrasonic bath for 30 minutes to further aid in clay deflocculation. Particle size was determined using a Malvern Mastersizer-S long bed laser analyzer. The sample was introduced into an aqueous medium and then pumped through the laser analyzer. The results of the analyses performed on sub-samples are similar, showing adequate reproducibility (fig. 6).

As can be seen in figure 6, the overall particle size of the mud sample is dominated by particles less than approximately 10 micrometers. A cumulative frequency plot of the same LUSI data compared to Hurricane Katrina flood sediments from New Orleans (fig. 7) shows that the LUSI mud is substantially finer-grained than Katrina flood sediments (Plumlee and others, 2007a). Nearly all of the LUSI particles are of the size range that could be incidentally ingested by hand-to-mouth contact. If dried and re-suspended as dusts, approximately 90 percent of the LUSI particles could be inhaled into the upper respiratory tract, and approximately 45 percent could be respired into the alveoli of the lung.

\section{Mud mineralogy}

X-ray diffraction and Scanning Electron Microscopy analyses of the mud (tables 3 and 4; fig. 8) indicate that it is dominated by clay minerals, with lesser amounts of organic material, quartz, and feldspars. In addition, pyrite (an iron sulfide), calcite (calcium carbonate) and other carbonates are present in levels up to several percent. The clay minerals are predominantly smectite, illite, and mixed illite/smectite, with lesser kaolinite and chlorite. Due to the complex mixture of clays in the sample, no commercial value of the clays is apparent.

SEM images confirm the fine-grained nature of the particles (fig. 8) as indicated by the particle size analysis. Clusters of pyrite crystals observed in SEM images (a texture termed "framboidal" due to its similar appearance to a raspberry) are diagnostic of an origin due to the bacterially catalyzed reduction of sulfate, followed by precipitation of the resulting reduced sulfur by iron in the sediment and pore waters. 


\section{Mud inorganic chemical composition}

Preliminary bulk inorganic chemical analyses of the LUSI mud are listed in table 5. Concentrations of arsenic, aluminum, iron, and vanadium in the mud exceed U.S. Environmental Protection Agency Region 9 residential soil Preliminary Remediation Goals (PRGs). The USEPA PRGs are "...tools for evaluating and cleaning up contaminated sites. They are risk-based concentrations that are intended to assist risk assessors and others in initial screening-level evaluations of environmental measurements." (U.S. Environmental Protection Agency, 2004). However, the PRGs for these elements are near or below the average western United States soil concentrations; for example, the average arsenic concentration in western U.S. soils is $5 \mathrm{ppm}$ (see table in Smith and Huyck, 1999), but the USEPA Region 9 PRG for arsenic varies from 0.4 to 0.6 $\mathrm{ppm}$. This illustrates the highly conservative nature of the PRGs from a risk perspective, and the challenge of meaningfully applying these PRGs to naturally occurring geologic materials.

\section{Mud organic chemical composition}

Organic chemical analyses of the LUSI mud sample are still ongoing. Preliminary qualitative results suggest the following findings:

- There is a petroliferous component in the mud. The oil appears very fresh, immature and nonbiodegraded. There is a complete suite of n-alkane compounds with a pattern typical of fresh petroleum. The presence of certain hopane compounds (C29 and C30) is also indicative of the presence of oil in the mud. The proportions of other compounds (pristane/phytane) indicate oxic conditions at formation and a likely coastal marine or terrigenous (land-based) source for the petroleum components. The dominance of a particular sterane (C27) also points to a terrigenous source.

- Several factors point to a low level of maturity for the organic matter in the mud and the presence of fresh nonbiodegraded oil. The presence of oleanane indicates a Cretaceous or younger age for the petrogenic material.

- The polycyclic aromatic hydrocarbons (PAHs) are very low in abundance. Those present indicate a petrogenic rather than combustion source.

Further studies are needed to quantify the concentrations of the various organic components in the mud, and to determine whether or not they are present in levels that exceed any sort of soil remediation or aquatic guidelines.

The mud sample contains low levels (tens of ppb) of the higher plant sterols including campesterol, stigmasterol, and beta-sitosterol. Also, 22-dehydrocholesterol (generally ascribed to algal material) is present at approximately $300 \mathrm{ppb}$. These compounds are derived from natural sources, are nonhazardous, and were likely entrained in the mud during ascent to the surface or mixed with the mud posteruption.

The organic compounds identified to date will likely exhibit a variety of environmental behaviors and effects. For example, some compounds will volatilize and phyto-oxidize (for example, light n-alkanes) or biodegrade (heavy n-alkanes) relatively quickly, and are relatively nontoxic. In contrast, heavy PAHs are persistent in the environment, and some are potentially carcinogenic. 


\section{Mud sulfur speciation}

Speciation of the inorganic sulfur forms in the LUSI mud (table 6) indicate a total sulfur content around 0.5 weight percent. Consistent with the finding that pyrite is present in the mud, the predominant form of sulfur is disulfide (the chemical formula for pyrite is $\mathrm{FeS}_{2}$ ). Small amounts of monosulfide and acid-soluble sulfate are also present. Photos of the mud that were posted at a number of sites on the Internet show that at times the mud has had a distinctly darker gray to blackish tint; such a color may indicate a higher level of monosulfide sulfur than has been analyzed in this sample.

\section{Net acid-production potential}

When pyrite and other iron sulfides are exposed at the earth's surface and weathered by rainwater and atmospheric oxygen, acidic and metalliferous drainage can result. Such waters can be detrimental to water quality and aquatic ecosystems into which the drainage waters flow (Plumlee and others, 1999). The presence of carbonate minerals in rocks or sediments that contain iron sulfides can help react with and consume the acid produced by sulfide oxidation.

The presence of pyrite in the LUSI mud raises the question as to whether the erupted mud may become acid-generating should it remain exposed at the ground surface and be weathered by rainwater and atmospheric oxygen. As a result, net acid-production (NAP) tests were applied to the LUSI sample; such tests were originally developed to predict whether sulfide-bearing mine wastes could develop acid-rock drainage (see Fey and others, 2000, and references therein). In these tests, a measured amount of material is oxidized completely with hydrogen peroxide; upon complete oxidation, the $\mathrm{pH}$ is measured, and the $\mathrm{pH}$ then titrated with a base to neutral $\mathrm{pH}$. By using the amount of base added, a value is calculated for the kilograms of calcium carbonate that would be needed to neutralize a tonne of the material to neutral $\mathrm{pH}$.

Results of an NAP test on the LUSI mud indicate a $\mathrm{pH}$ following hydrogen-peroxide oxidation of 7.7 (table 7). As this is greater than neutral $\mathrm{pH}$, the resulting NAP value is 0 , indicating that this mud sample would likely not become acid generating if completely oxidized. The acid generated by oxidation of pyrite and iron monosulfides in the mud is likely counterbalanced by the neutralizing potential imparted by carbonates, and possibly organic components, in the mud.

\section{Insights from the Mud and Water Analytical Results}

The analytical results for a single 1-liter sample of the LUSI mud and separated water are not representative of the likely substantial variations in composition of the more than 30 million cubic meters of mud that have erupted to date. Further, the mud sample is likely not fully representative of all the mud that was erupting at the time of collection. Given these caveats, the analytical findings to date provide some intriguing insights into the potential environmental behavior of the mud that was erupting at the time of collection, and its characteristics of potential environmental and health concern.

The solid component of the mud sample does not contain highly elevated levels of potentially toxic heavy metals. Nor does the mud sample appear to have any substantial potential to generate acid drainage due to sulfide oxidation. However, several elements, most notably arsenic, are present in concentrations in the mud that exceed USEPA 
remedial guidelines for residential soils but that are near or below average U.S. soil concentrations. Analyses have identified a complex mixture of organic compounds likely to have been derived from petroleum source rocks. Further analyses are needed to determine whether concentrations of any of these organic compounds exceed known soil guideline concentrations.

Particle-size analysis suggests that if erupted mud similar to the analyzed sample is dried and disturbed to produce dusts, then a substantial component (around 45 percent) of the mud is of sufficiently fine size to be respired into the deeper portions of the respiratory system. Also, a substantial component of the mud sample is of sufficiently small size that it could be inadvertently ingested via hand-to-mouth contact, particularly by younger children playing in or otherwise coming into contact with wet or dried mud.

Water that is derived from settling mud deposits may have the potential to adversely affect the quality of surface- or ground-water sources for drinking water, through the effects of several constituents such as fluoride, nitrate, iron, manganese, aluminum, sulfate, chloride, and total dissolved solids. Of these, fluoride and nitrate are perhaps of the greatest potential concern due to their elevated concentrations in the waters.

Some proportion of the erupted mud is presently being channeled into the Kali Porong waterway, where it is eventually carried to the ocean. In addition to the effects of the mud on these aquatic ecosystems from a particulate or physical-sedimentation standpoint, further work is needed to see if any mud components pose a specific chemical threat to aquatic organisms that inhabit portions of the river and ocean affected by the mud. For example, toxicity testing of the muds and separated waters may provide insights into whether particular constituents pose toxicity threats to some aquatic organisms.

Stable hydrogen and oxygen isotopic composition of the waters accompanying the mud are fully compatible with an origin as sedimentary formation waters. This result indicates that, at least at the time of sample collection, the mud eruption did not have a significant component of magmatic waters.

\section{Gas Eruptions}

This study did not analyze the gases erupted with the mud or that recently began seeping or erupting into nearby villages (Davies and others, 2008), and so it is possible only to speculate about their potential composition. The gas composition in mud-volcano systems varies by region but is generally dominated by methane, up to 99 percent, (Dimitrov, 2002), which accounts for the explosive combustibility of the LUSI gas. Lesser amounts of carbon dioxide and nitrogen are usually present (Etiope and others, 2002). Hydrogen sulfide can be a significant component of the total gas (Martinelli and Giovanni, 2005), which is consistent with the rotten-egg smell observed at the LUSI eruption crater. The petroleum-rich nature of the organic matter in the LUSI mud indicates that higher hydrocarbon gases such as ethane, propane, and possibly butane and low-molecular-weight PAHs, may also be present at low levels (Dimitrov 2002b). 


\section{Suggested Further Studies}

The analytical results to date suggest that a variety of additional studies could provide important further insights into the potential environmental behavior and environmental health characteristics of the erupted mud.

- Studies are needed to develop a better understanding of how the mud may have changed in characteristics over time. For example, stratigraphically controlled analyses of cores systematically collected from multiple places within the erupted mud deposits will provide further information about how the mud may have changed over the course of the eruption.

- Studies of samples collected from dried mud deposits are needed to determine whether or not any of the mud deposits may generate acidic drainage, and to better understand changes in makeup of the mud deposits as they weather and undergo repeated wet-dry cycles during and between rainy periods. Such studies should include, for example, characterization of secondary minerals formed by weathering and evaporation of water, and leach tests to examine potential water reactivity and water-leaching potential of the mud (Hageman, 2007).

- A more rigorous sampling and analysis is needed of the water separated from the mud, with appropriate filtering and preservation methods applied in the field. Field tests that analyze for ammonia should be applied in order to evaluate how much of the nitrate is produced by oxidation of ammonia.

- Detailed chemical analysis of rainwater that falls on, ponds upon, or runs off from the mud deposits is needed to better assess for potential effects on water quality.

- Sampling of airborne dusts generated from dried mud deposits may help to better understand potential health impacts of the dusts.

- Monitoring of any drinking-water supplies present in the area of influence of the erupted mud and water, as well as rainwater runoff, may be needed to assess effects on drinking-water quality. Of particular note is potential contamination by fluoride, nitrate, chloride, iron, aluminum, and suspended solids.

- A detailed characterization of the river and marine aquatic habitat affected by the mud is needed in order to help understand potential effects of the ongoing mud disposal into the river and ocean. This is particularly needed because of the substantial aquaculture industry along the coast adjacent to the Kali Porong river mouth. Aquatic toxicity testing (similar to the study of Carr and others, 2001) of the mud on marine organisms may also help in this regard. An assessment is also needed to examine the potential for mud discharged into the river and marine environment to result in nitrate-generated algal blooms and resulting hypoxia.

- The microbiological characteristics of the mud over time should be analyzed, to determine if there are pathogens present that could be deleterious to human or ecosystem health. While the hot mud as erupted from depth might not be a likely host for microbial pathogens, pathogen communities might develop in the mud following eruption, especially given the ambient moisture and humidity, and the abundant petrogenetic organic matter in the mud that could serve as a nutrient source for microbes.

- Further evaluation of the dewatering characteristics and mechanical stability of the accumulated mud should be carried out by appropriate engineering experts. 
- Detailed analyses of the chemical composition of the erupted gas and gas seeps over time, coupled with stable carbon, hydrogen, and sulfur isotopic composition of the various gas components would help provide insights in to the sources of the gas and changing conditions at depth beneath the eruption crater.

\section{USGS Contacts}

- Tom Casadevall (sample collection and project coordination) - tcasadev@usg.gov

- Geoff Plumlee (analytical coordination and interpretation) - gplumlee@usgs.gov

\section{References Cited}

Carr, R.S., Nipper, M., and Plumlee, G.S. , 2001, A preliminary survey of marine contamination from mining-related activities on Marinduque Island, Philipines: porewater toxicity and chemistry results from a field trip - October 14-19, 2000: U.S. Geological Survey Open-File Report 01-0441, 61 p., http://pubs.usgs.gov/of/2001/ofr-01-0441/.

Clark, R.N., Green, R.O., Swayze, G.A., Meeker, G., Sutley, S., Hoefen, T.M., Livo, K.E., Plumlee, G., Pavri, B., Sarture, C., Wilson, S., Hageman, P., Lamothe, P., Vance, J. S., Boardman, J., Brownfield, I., Gent, C., Morath, L.C., Taggart, J., Theodorakos, P.M., and Adams, M., 2001, Environmental studies of the World Trade Center area after the September 11, 2001, attack: U.S. Geological Survey Open-File Report 01-0429, http://pubs.usgs.gov/of/2001/ofr-01-0429/.

Clark, R.N., Swayze, G.A., Hoefen, T.M., Green, R.O., Livo, K.E., Meeker, G., Sutley, S., Plumlee, G., Pavri, B., Sarture, C., Boardman, J., Brownfield, I., Morath, L.C., 2005, Environmental mapping of the World Trade Center area with imaging spectroscopy after the September 11, 2001, attack, in Gaffney, J.S., and Marley, N.A., eds., Urban aerosols and their impacts: Lessons learned from the World Trade Center tragedy: American Chemical Society Symposium Series 919, Oxford University Press, p. 66-83.

Cyranowski, David, 2007, Muddy waters-How did a mud volcano come to destroy and Indonesian town?: Nature, v. 45, p. 812-814.

Davies, E., Heriwati, R., Richardson, A., 2008a, Indonesians in Java village scared by seeping gas: Reuters, March 5, 2008, http://www.reuters.com/article/scienceNews/idUSJAK29258220080305, accessed March 17, 2008.

Davies, R.J., Brumm, M., Manga, M., Rubiandini, R., Swarbick, R., and Tingay, M., 2008b, The East Java mud volcano (2006 to present): An earthquake or drilling trigger?: Earth and Planetary Science Letters In Press, Corrected Proof, http://www.sciencedirect.com/science/ article/B6V61-4SNWW5R-5/1/58c8051d987a39574315bdb774d775ee, accessed June, 2008.

Davies, R.J., Swarbick, R.E., Evans, R.J., Huuse, M., 2007, Birth of a mud volcano: East Java, 29 May 2006: GSA Today, v. 17, p. 4-9.

Dimitrov, L.I., 2002, Mud volcanoes-The most important pathway for degassing deeply buried sediments. Earth-Science Reviews, v. 59, p. 49-76.

Dimitrov, L.I., 2002b, Mud volcanoes-A sizable source of atmospheric methane: VII International Conference on Gas in Marine Sediments, Baku, Azerbaijan, October 2002, abstracts volume 33. 
Etiope G., A. Caracausi, R. Favara, F. Italiano, and C. Baciu, 2002, Methane emission from the mud volcanoes of Sicily (Italy): Geophysical Research Letters, v. 29, no. 8, p. 1215.

Fey, D.L., Desborough, G.A., and Church, S.E., 2000, Comparisons of two leach procedures applied to metal-mining related wastes in Colorado and Montana and a relative ranking method for mine wastes: Proceedings of the Fifth International Conference on Acid Rock Drainage, May 21-24, 2000, v. 2, p. 1477-1487, Society for Mining, Metallurgy, and Exploration, Inc., Littleton, Colo.

Hageman, P.L., 2007, U.S. Geological Survey field leach test for assessing water reactivity and leaching potential of mine wastes, soils, and other geologic and environmental materials: U.S. Geological Survey Techniques and Methods Report 5-D3, http://pubs.usgs.gov/tm/2007/05D03/pdf/TM5-D3 508.pdf.

Kendall, C., and Coplen, T.B., 1985, Multisample conversion of water to hydrogen by zinc for stable isotope determination: Analytical Chemistry, v. 57, p. 1437-1440.

Kharaka, Y.K., and Hanor, J.S., 2007, Deep fluids in the continents-I. Sedimentary basins, in Drever, J.I., ed., Surface and ground water, weathering, and soils: Treatise on Geochemistry, online version, v. 5, p. 1-48, http://www.sciencedirect.com/science/referenceworks/9780080437514, accessed March 2008.

Kishima, N., and Sakai, H., 1980, Oxygen-18 and deuterium determination on a single water sample of a few milligrams: Analytical Chemistry, v. 52, p. 356-358.

Kvenvolden, K.A., Hostettler. F.D., Carlson, P.R., Rapp, J.B. Threlkeld, C.N., and Warden, A. 1995, Ubiquitous tar balls with a California-source signature on the shorelines of Prince William Sound, Alaska: Environmental Science and Technology, v. 10, p. 2684-2694.

Kvenvolden, K.A., Hostettler. F.D., Rosenbauer, R.J., Lorenson, T.L., Castle, W.T., and Sugarman, S., 2002, Hydrocarbons in recent sediment of the Monterey Bay National Marine Sanctuary: Marine Geology, v. 181, p. 101-113.

Manga, M., 2007, Did an earthquake trigger the May 2006 eruption of the Lusi mud volcano?: Eos, v. 88, p. 201.

Marshall, A., 2008, Drowning in mud: National Geographic Online, 2 p., http://ngm.nationalgeographic.com/ngm/2008-01/volcano-culture/drowning-inmud.html, accessed January 2008.

Martinelli, G., and Panahi, B. 2005, Mud volcanoes, geodynamics and seismicityProceedings of the NATO Advanced Research Workshop on Mud Volcanism, Geodynamics and Seismicity, Baku, Azerbaijan, IV: Earth and Environmental Sciences, Springer, v. 51, 288 p.

Mazzini, A., Svensen, H., Akhmanov, Aloisi, G., Planke, S., Malthe-Sørenssen, A., and Istadi, B., 2007, Triggering and dynamic evolution of the LUSI mud volcano, Indonesia: Earth and Planetary Science Letters, v. 261, p. 375-388.

Meeker, G.P., Sutley, S.J., Brownfield, I.K., Lowers, H.A., Bern, A.M., Swayze, G.A., Hoefen, T.M., Plumlee, G.S., Clark, R.N., and Gent, C.A., 2005, Materials characterization of dusts generated by the collapse of the World Trade Center, in Gaffney, J.S., and Marley, N.A., eds., Urban aerosols and their impacts: Lessons learned from the World Trade Center tragedy: American Chemical Society Symposium Series 919, Oxford University Press, p. 84-102. 
Plumlee, G.S., Foreman, W.T., Griffin, D.W., Lovelace, J.K., Meeker, G.P., and Demas, C.R., 2007a, Characterization of flood sediments from Hurricane Katrina and Rita and potential implications for human health and the environment, in Farris, G.S., Smith, G.J., Crane, M. P., Demas, C.R., Robbins, L.L., and Lavoie, D.L.,eds., Science and the storms: the USGS response to the hurricanes of 2005: U.S. Geological Survey Circular 1306, p. 246-257.

Plumlee, G.S., Hageman, P.L., Lamothe, P.J., Ziegler, T.L., Meeker, G.P., Theodorakos, P., Brownfield, I., Adams, M., Swayze, G.A., Hoefen, T., Taggart, J.E., Clark, R.N., Wilson, S., and Sutley, S., 2005, Inorganic chemical composition and chemical reactivity of settled dust generated by the World Trade Center building collapse, in Gaffney, J.S., and Marley, N.A., eds., Urban aerosols and their impacts: Lessons learned from the World Trade Center tragedy: American Chemical Society Symposium Series 919, Oxford University Press, p. 238-276.

Plumlee, G.S., Martin, D.A., Hoefen, T., Kokaly, R., Hageman, P., Eckberg, A., Meeker, G.P., Adams, M., Anthony, M., and Lamothe, P.J., 2007b, Preliminary analytical results for ash and burned soils from the October 2007 Southern California Wildfires: U.S. Geological Survey Open-File Report 2007-1407, 13 p., http://pubs.usgs.gov/of/2007/1407.

Plumlee, G.S., Morman, S.A., and Ziegler, T.L., 2006, The toxicological geochemistry of earth materials: an overview of processes and the interdisciplinary methods used to study them, in Sahai, N., and Schoonen, M., eds., Medical mineralogy and geochemistry: Reviews in Mineralogy and Geochemistry, v. 64, , p. 5-58.

Plumlee, G.S., Smith, K.S., Montour, M.R., Ficklin, W.H., and Mosier, E.L., 1999, Geologic controls on the composition of natural waters and mine waters draining diverse mineral-deposit types, in Filipek, L.H., and Plumlee, G.S., eds., The environmental geochemistry of mineral deposits - Part B: case studies and research topics: Reviews in Economic Geology, v. 6B, Littleton, Colorado, Society of Economic Geologists, Inc., p. 373-432.

Smith, K.S., and Huyck, H.L.O., 1999, An overview of the abundance, relative mobility, bioavailability, and human toxicity of metals, in Plumlee, G.S., and Logsdon, M.J., eds., The environmental geochemistry of mineral deposits-Part A: processes, techniques, and health issues,: Reviews in Economic Geology, v. 6A, Littleton, Colorado, Society of Economic Geologists, Inc., p. 29-70.

Swayze, G.A., Hoefen, T.M., Sutley, S.J., Clark, R.N., Livo, K.E., Meeker, G.P., Plumlee, G.S., Morath, L.C., and Brownfield, I.K., 2005, Spectroscopic and X-ray diffraction analyses of asbestos in the World Trade Center dust: in Gaffney, J.S., and Marley, N.A., eds., Urban aerosols and their impacts: Lessons learned from the World Trade Center tragedy: American Chemical Society Symposium Series 919, Oxford University Press, p. 40-65.

Taggart, J.E., Jr., ed., 2002, Analytical methods for chemical analysis of geologic and other materials: U.S. Geological Survey Open-File Report 02-0223, http://pubs.usgs.gov/of/2002/ofr-02-0223/. 
United Nations Environment Program/Office for the Coordination of Humanitarian Afffairs, 2006, Environmental Assessment - Hot Mud Flow East Java, Indonesia: United Nations Disaster Assessment and Coordination Mission Final Technical Report, Joint UNEP/OCHA Environment Unit, 56 p., http://www.un.or.id/upload/lib/Indonesia_Hot_Mud_Flow_East_Java_final_report.pdf

U.S. Environmental Protection Agency, 2003, National primary and secondary drinking water regulations: U.S. Environmental Protection Agency, http://www.epa.gov/safewater/contaminants/index.html, accessed May, 2008.

U.S. Environmental Protection Agency, 2004, U.S. Environmental Protection Agency, Region 9, Preliminary remediation goals, http://www.epa.gov/region09/waste/sfund/prg/index.html - prgtable, accessed May, 2008.

U.S. Environmental Protection Agency, 2006, National recommended water quality criteria: U.S. Environmental Protection Agency, http://www.epa.gov/waterscience/criteria/nrwqc-2006.pdf, accessed May, 2008.

U.S. Geological Survey (2006) Poster of the Java, Indonesia earthquake of 26 May 2006 - Magnitude 6.3: U.S. Geological Survey Earthquake Summary Poster, http://earthquake.usgs.gov/eqcenter/eqarchives/poster/2006/20060526.php, accessed May, 2008. 


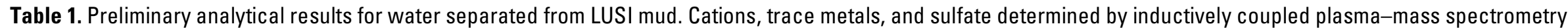
(ICP-MS) (Taggart, 2002). Anions determined by ion chromatography (IC). Note good agreement between sulfate analyses via IC and ICP-MS. Spec. Cond. - Specific

Conductance; Disso. Org. C - Dissolved organic carbon; Alk. - Alkalinity; nr - not reported. * Concentrations of iron and aluminum likely represent substantial colloida contributions, as the samples were filtered only to $0.45 \mu \mathrm{m}$ prior to analysis (see discussion in Kharaka and Hanor, 2007). ${ }^{* *}$ Concentrations of Se and As are possibly artificially elevated due to interferences from chloride ions in the ICP-MS analytical device.

\begin{tabular}{|c|c|c|c|c|c|c|c|c|c|c|c|c|c|c|}
\hline pH & $\begin{array}{c}\text { Spec. } \\
\text { Cond. } \\
\text { (mS/cm) }\end{array}$ & $\begin{array}{l}\text { Diss. } \\
\text { Org. C } \\
\text { (mg/L) }\end{array}$ & $\begin{array}{c}\text { Alk. } \\
\text { (mg/L } \\
\text { CaCo3) }\end{array}$ & $\begin{array}{c}F \\
(\mathrm{mg} / \mathrm{L})\end{array}$ & $\underset{(\mathrm{mg} / \mathrm{L})}{\mathrm{Cl}}$ & $\begin{array}{c}\mathrm{NO}_{3} \\
(\mathrm{mg} / \mathrm{L})\end{array}$ & $\begin{array}{c}\mathrm{SO}_{4} \\
(\mathrm{mg} / \mathrm{L} \text {, } \\
\text { by IC) }\end{array}$ & $\underset{(\mu \mathrm{g} / \mathrm{L})}{\mathrm{Ag}}$ & $\underset{(\mu \mathrm{g} / \mathrm{L})}{\mathrm{Al}}$ & $\underset{(\mu \mathrm{g} / \mathrm{L})}{\mathrm{As}}$ & $\underset{(\mu \mathrm{g} / \mathrm{L})}{\mathrm{Au}}$ & $\underset{(\mu \mathrm{g} / \mathrm{L})}{\mathrm{Ba}}$ & $\underset{(\mu \mathrm{g} / \mathrm{L})}{\mathrm{Be}}$ & $\begin{array}{c}B i \\
(\mu \mathrm{g} / \mathrm{L})\end{array}$ \\
\hline
\end{tabular}

\begin{tabular}{|c|c|c|c|c|c|c|c|c|c|c|c|c|c|c|c|}
\hline 7.42 & 37.6 & 220 & 236 & 34 & 1470 & 169 & 306 & & $<3$ & *284 & $* * 58.9$ & 9.04 & 1970 & 0.4 & $<0.2$ \\
\hline$\underset{(\mathrm{mg} / \mathrm{L})}{\mathrm{Ca}}$ & $\begin{array}{c}\text { Cd } \\
(\mu g / L)\end{array}$ & $\begin{array}{c}\mathrm{Ce} \\
(\mu \mathrm{g} / \mathrm{L})\end{array}$ & $\begin{array}{c}\mathrm{Cr} \\
(\mu \mathrm{g} / \mathrm{L})\end{array}$ & $\underset{(\mu \mathrm{g} / \mathrm{L})}{\mathrm{Cs}}$ & $\underset{(\mu \mathrm{g} / \mathrm{L})}{\mathrm{Cu}}$ & $\begin{array}{c}\text { Dy } \\
(\mu g / L)\end{array}$ & $\begin{array}{c}\text { Er } \\
(\mu g / L)\end{array}$ & $\underset{(\mu g / L)}{E u}$ & $\underset{(\mu \mathrm{g} / \mathrm{L})}{\mathrm{Fe}}$ & $\begin{array}{c}\text { Ga } \\
(\mu \mathrm{g} / \mathrm{L})\end{array}$ & $\begin{array}{c}\text { Gd } \\
(\mu g / L)\end{array}$ & $\underset{(\mu g / L)}{G e}$ & $\begin{array}{c}\text { Ho } \\
(\mu \mathrm{g} / \mathrm{L})\end{array}$ & $\begin{array}{c}K \\
(\mathrm{mg} / \mathrm{L})\end{array}$ & $\begin{array}{c}\mathrm{La} \\
(\mu \mathrm{g} / \mathrm{L})\end{array}$ \\
\hline 811 & 0.07 & 0.15 & 12.7 & 4.18 & 3 & 0.04 & 0.03 & 0.23 & ${ }^{*} 1210$ & 0.27 & 0.02 & 11.4 & $<0.005$ & 92 & 0.09 \\
\hline$\underset{(\mu \mathrm{L} / \mathrm{L})}{\mathrm{Li}}$ & $\begin{array}{c}\text { Lu } \\
(\mu \mathrm{g} / \mathrm{L})\end{array}$ & $\underset{(\mathrm{mg} / \mathrm{L})}{\mathrm{Mg}}$ & $\begin{array}{c}M n \\
(\mu \mathrm{g} / \mathrm{L})\end{array}$ & $\begin{array}{c}\text { Mo } \\
(\mu \mathrm{g} / \mathrm{L})\end{array}$ & $\begin{array}{c}\mathrm{Na} \\
(\mathrm{mg} / \mathrm{L})\end{array}$ & $\begin{array}{c}\mathrm{Nb} \\
(\mu \mathrm{g} / \mathrm{L})\end{array}$ & $\begin{array}{c}\text { Nd } \\
(\mu \mathrm{g} / \mathrm{L})\end{array}$ & $\underset{(\mu \mathrm{g} / \mathrm{L})}{\mathrm{Ni}}$ & $\begin{array}{c}P \\
(\mathrm{mg} / \mathrm{L})\end{array}$ & $\begin{array}{c}\mathrm{Pb} \\
(\mu \mathrm{g} / \mathrm{L})\end{array}$ & $\underset{(\mu \mathrm{g} / \mathrm{L})}{\mathrm{Pr}}$ & $\begin{array}{c}\mathbf{R b} \\
(\mu \mathrm{g} / \mathrm{L})\end{array}$ & $\begin{array}{c}S b \\
(\mu g / L)\end{array}$ & $\begin{array}{c}S c \\
(\mu \mathrm{g} / \mathrm{L})\end{array}$ & $\begin{array}{c}\mathrm{Se} \\
(\mu \mathrm{g} / \mathrm{L})\end{array}$ \\
\hline 4470 & $<0.1$ & 201 & 517 & 4.9 & $\mathrm{nr}$ & $<0.2$ & 0.06 & 24.5 & 0.2 & 0.2 & $<0.01$ & 45.8 & $<0.3$ & 11 & ${ }^{* *} 228$ \\
\hline$\underset{(\mu g / L)}{S m}$ & $\begin{array}{c}\text { S04 } \\
\text { (mg/L, } \\
\text { by ICP- } \\
\text { MS) }\end{array}$ & $\underset{(\mu \mathrm{g} / \mathrm{L})}{\mathrm{Sr}}$ & $\begin{array}{c}\mathrm{Ta} \\
(\mu \mathrm{g} / \mathrm{L})\end{array}$ & $\begin{array}{c}\mathrm{Tb} \\
(\mu \mathrm{g} / \mathrm{L})\end{array}$ & $\begin{array}{c}\mathrm{Th} \\
(\mu \mathrm{g} / \mathrm{L})\end{array}$ & $\begin{array}{c}\mathrm{Ti} \\
(\mu \mathrm{g} / \mathrm{L})\end{array}$ & $\begin{array}{c}\mathrm{Tl} \\
(\mu \mathrm{g} / \mathrm{L})\end{array}$ & $\underset{(\mu \mathrm{g} / \mathrm{L})}{\mathrm{Tm}}$ & $\underset{(\mu \mathrm{g} / \mathrm{L})}{\mathbf{U}}$ & $\begin{array}{c}V \\
(\mu g / L)\end{array}$ & $\begin{array}{c}W \\
(\mu g / L)\end{array}$ & $\begin{array}{c}Y \\
(\mu g / L)\end{array}$ & $\begin{array}{c}\text { Yb } \\
(\mu \mathrm{g} / \mathrm{L})\end{array}$ & $\begin{array}{c}\mathrm{Zn} \\
(\mu \mathrm{g} / \mathrm{L})\end{array}$ & $\begin{array}{c}\mathrm{Zr} \\
(\mu \mathrm{g} / \mathrm{L})\end{array}$ \\
\hline$<0.01$ & 297 & 48400 & 0.07 & $<0.005$ & $<0.2$ & 31.3 & 0.1 & $<0.005$ & 0.22 & 115 & $<0.5$ & 0.39 & 0.03 & 5.7 & 0.2 \\
\hline
\end{tabular}


Table 2. Preliminary analytical results for the hydrogen and oxygen isotopic composition of water from LUSI mud. The values presented are averages of duplicate analyses. VSMOW - Vienna Standard Mean Ocean Water.

\begin{tabular}{|c|c|}
\hline 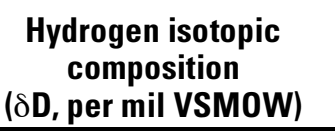 & $\begin{array}{c}\text { Oxygen isotopic composition } \\
\left(\delta^{18} 0 \text {, per mil VSMOW }\right)\end{array}$ \\
\hline & +8.5 \\
\hline
\end{tabular}

Table 3. Semi-quantitative XRD analytical results on the LUSI mud.

\begin{tabular}{lr}
\hline Mineral & Percent \\
\hline Quartz & 22 \\
Feldspar (combined) & 2 \\
Calcite & 1.5 \\
Pyrite & 0.5 \\
Organic matter & 14 \\
Clay minerals: & \\
Smectite & 16 \\
Illite + iliite/smectite & 24 \\
Kaolinite & 12 \\
Chlorite & 8 \\
\hline
\end{tabular}

Table 4. SEM modal analysis of LUSI mud. The sample was suspended in water and then filtered. Mineral identification tentatively based on semi-quantitative energy dispersive X-ray analysis of individual particle compositions. Altogether, 144 grains were analyzed. ${ }^{*}$ Calcite may also be present as fine-grained coatings on particles. **Unidentified phases include manganese-rich particles, and $\mathrm{Ca}-\mathrm{Fe}-\mathrm{Mg}$ carbonates.

\begin{tabular}{lr} 
Mineral & Percent \\
\hline Clay & 73.6 \\
Quartz & 8.3 \\
Feldspar & 5.6 \\
Pyrite & 3.5 \\
Calcite* & 1.4 \\
Titanium oxide & 1.4 \\
Apatite & 0.7 \\
Unidentified $^{* *}$ & 5.6 \\
\hline
\end{tabular}


Table 5. Bulk chemical composition of LUSI mud sample and duplicate split ("mud dup") as determined by ICP-MS and (for mercury) continuous flow-cold vaporatomic absorption spectrometry. "EPA Res. Soil PRG" is the U.S. Environmental Protection Agency (2004) Region 9 residential soil preliminary remediation goal (PRG) for the cleanup of contaminated residential soils. PRGs for arsenic are based on a cancer endpoint. PRGs vary for chromium, depending upon the proportion of hexavalent chromium (VI) compared to trivalent chromium (III) present.

\begin{tabular}{|c|c|c|c|c|c|c|c|c|c|c|c|}
\hline & Ag ppm & Al ppm & As ppm & Ba ppm & Be ppm & Bi ppm & Ca ppm & Cd ppm & Ce ppm & Co ppm & Cr ppm \\
\hline LUSI mud & $<2$ & 81700 & 8.8 & 178 & 1.6 & 0.33 & 14300 & 0.09 & 47.4 & 16.0 & 90.1 \\
\hline LUSI mud dup & $<2$ & 85400 & 9.1 & 179 & 1.6 & 0.34 & 14500 & 0.09 & 51.4 & 15.9 & $\begin{array}{r}91.1 \\
210(1 / 6 \\
\text { VI/III), } 30 \\
\text { (all VI), } \\
100000 \text { (all }\end{array}$ \\
\hline PRG & 390 & 76000 & $0.39-0.62$ & 5400 & 150 & & & 37 & & 900 & III) \\
\hline
\end{tabular}

\begin{tabular}{|c|c|c|c|c|c|c|c|c|c|c|c|}
\hline & Cs ppm & Cu ppm & Dy ppm & Er ppm & Eu ppm & Fe ppm & Ga ppm & Gd ppm & Ho ppm & K ppm & La ppm \\
\hline LUSI mud & 8.6 & 24.6 & 3.4 & 1.9 & 1.1 & 49000 & 19.5 & 0.66 & 0.68 & 14800 & 22.2 \\
\hline $\begin{array}{l}\text { LUSI mud dup } \\
\text { EPA res. Soil }\end{array}$ & 8.8 & 24.7 & 3.6 & 2.0 & 1.1 & 49000 & 19.5 & 0.64 & 0.68 & 15000 & 22.8 \\
\hline PRG & & 3100 & & & & 23000 & & & & & \\
\hline
\end{tabular}

\begin{tabular}{|c|c|c|c|c|c|c|c|c|c|c|c|}
\hline & Li ppm & Mg ppm & Mn ppm & Mo ppm & Na ppm & $\mathrm{Nb}$ ppm & Nd ppm & Ni ppm & P ppm & $\mathrm{Pb}$ ppm & Pr ppm \\
\hline LUSI mud & 85.3 & 11900 & 915 & 1.3 & 12200 & 7.0 & 22.1 & 26.6 & 452 & 18.5 & 5.5 \\
\hline $\begin{array}{l}\text { LUSI mud dup } \\
\text { EPA res. Soil }\end{array}$ & 86.6 & 12300 & 934 & 1.3 & 12800 & 7.6 & 22.1 & 27.1 & 465 & 18.8 & 5.8 \\
\hline PRG & 1600 & & 1800 & 390 & & & & 1600 & & $150-400$ & \\
\hline
\end{tabular}

\begin{tabular}{|c|c|c|c|c|c|c|c|c|c|c|c|}
\hline & Rb ppm & Sb ppm & Sc ppm & Se ppm & Sm ppm & Sr ppm & Ta ppm & Tb ppm & Th ppm & Ti ppm & TI ppm \\
\hline LUSI mud & 73.0 & 0.49 & 14.6 & $<1$ & 4.5 & 292 & 0.57 & 4.0 & 8.82 & 4010 & 0.42 \\
\hline $\begin{array}{l}\text { LUSI mud dup } \\
\text { EPA res. Soil }\end{array}$ & 73.3 & 0.50 & 15.8 & $<1$ & 4.8 & 292 & 0.57 & 4.2 & 8.95 & 4120 & 0.42 \\
\hline & & 31 & & & & & & & & & 5.2 \\
\hline
\end{tabular}

\begin{tabular}{lrrrrrrr} 
& Tm ppm & \multicolumn{1}{c}{ U ppm } & \multicolumn{1}{c}{ V ppm } & \multicolumn{1}{c}{ Y ppm } & Yb ppm & Zn ppm & Hg ppm \\
\hline LUSI mud & 0.26 & 2.10 & 131 & 16.2 & 1.8 & 95.3 & 0.02 \\
LUSI mud dup & 0.29 & 2.15 & 130 & 17.1 & 2.0 & 95.3 & 0.02 \\
EPA Res. Soil & & 16 & 78 & & & 23000 & 23 \\
PRG & & & & & & & \\
\hline
\end{tabular}


Table 6. Sulfur speciation of the LUSI mud.

\begin{tabular}{|c|c|c|c|c|}
\hline Sulfur type & Soil sample & $\begin{array}{c}\text { Total dry } \\
\text { sample mass } \\
\text { (grams) }\end{array}$ & $\begin{array}{l}\text { Sulfur content } \\
\text { (grams) }\end{array}$ & $\begin{array}{l}\text { Percent sulfur/ } \\
\text { sample }\end{array}$ \\
\hline Monosulfide & $\begin{array}{c}\text { LUSI } \\
\text { LUSI duplicate }\end{array}$ & $\begin{array}{l}4.4 \\
4.4\end{array}$ & $\begin{array}{l}0.003 \\
0.002\end{array}$ & $\begin{array}{l}0.07 \\
0.04\end{array}$ \\
\hline Acid-Soluble $\mathrm{SO}_{4}(6 \mathrm{~N})$ & $\begin{array}{c}\text { LUSI } \\
\text { LUSI duplicate }\end{array}$ & $\begin{array}{l}4.4 \\
4.4\end{array}$ & $\begin{array}{l}0.0002 \\
0.0005\end{array}$ & $\begin{array}{c}0.006 \\
0.01\end{array}$ \\
\hline Disulfide & $\begin{array}{c}\text { LUSI } \\
\text { LUSI duplicate }\end{array}$ & $\begin{array}{l}4.4 \\
4.4\end{array}$ & $\begin{array}{l}0.02 \\
0.02\end{array}$ & $\begin{array}{l}0.4 \\
0.4\end{array}$ \\
\hline Total Sulfur & $\begin{array}{c}\text { LUSI } \\
\text { LUSI duplicate }\end{array}$ & $\begin{array}{l}4.4 \\
4.4\end{array}$ & $\begin{array}{l}0.02 \\
0.02\end{array}$ & $\begin{array}{l}0.5 \\
0.4\end{array}$ \\
\hline
\end{tabular}

Table 7. Results of a NAP test on the LUSI mud. See Fey and others (2000) and references therein for a summary of this test and results for various mine waste piles.

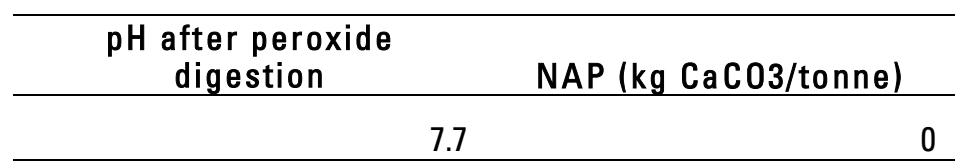




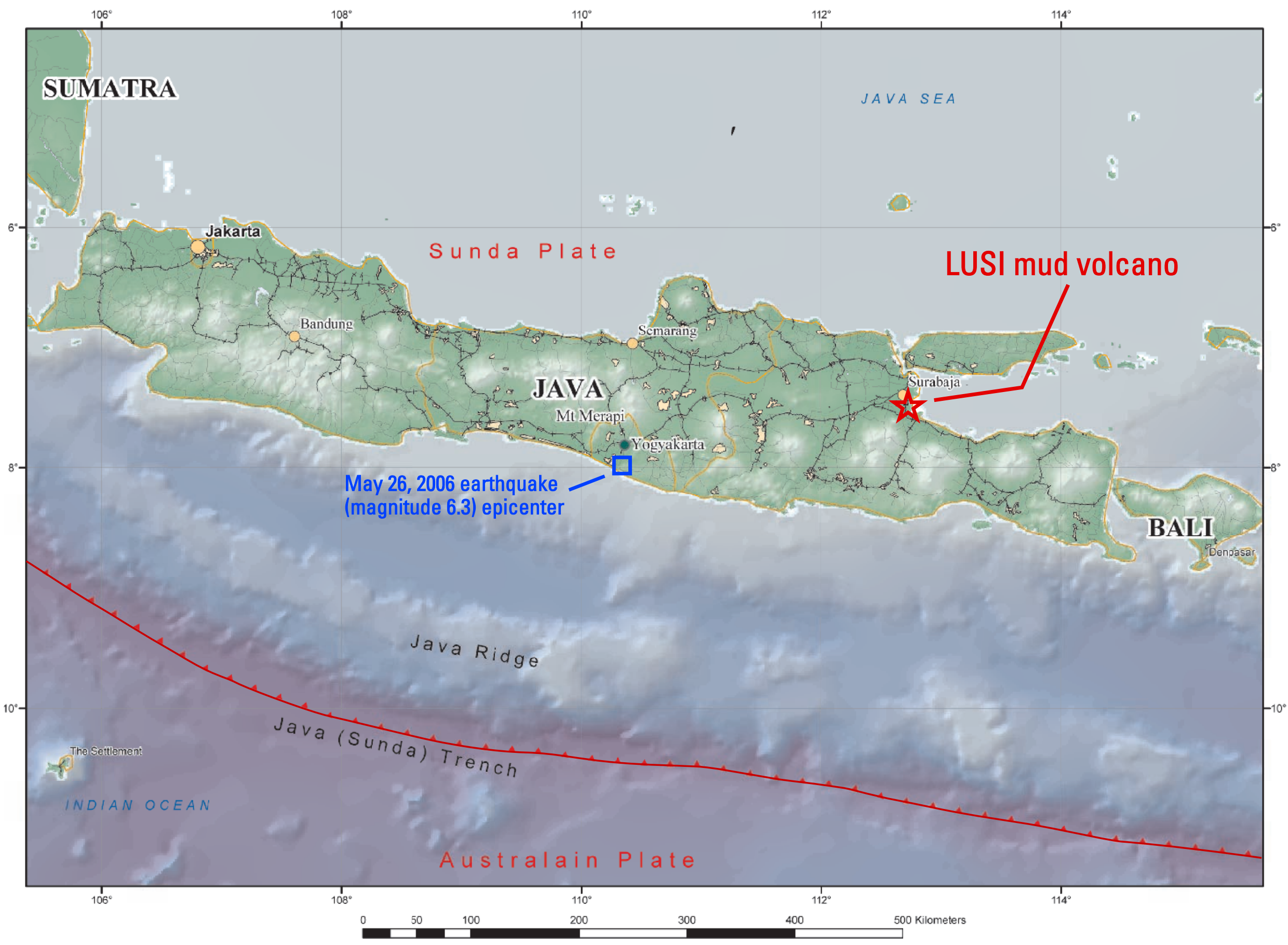

Figure 1. Map of Java showing the location (star) of the LUSI mud volcano in eastern Java south of Surabaja. The epicenter of the May 26, 2006, Yogyakarta earthquake, is shown by the blue square. Map after U.S. Geological Survey (2006). 


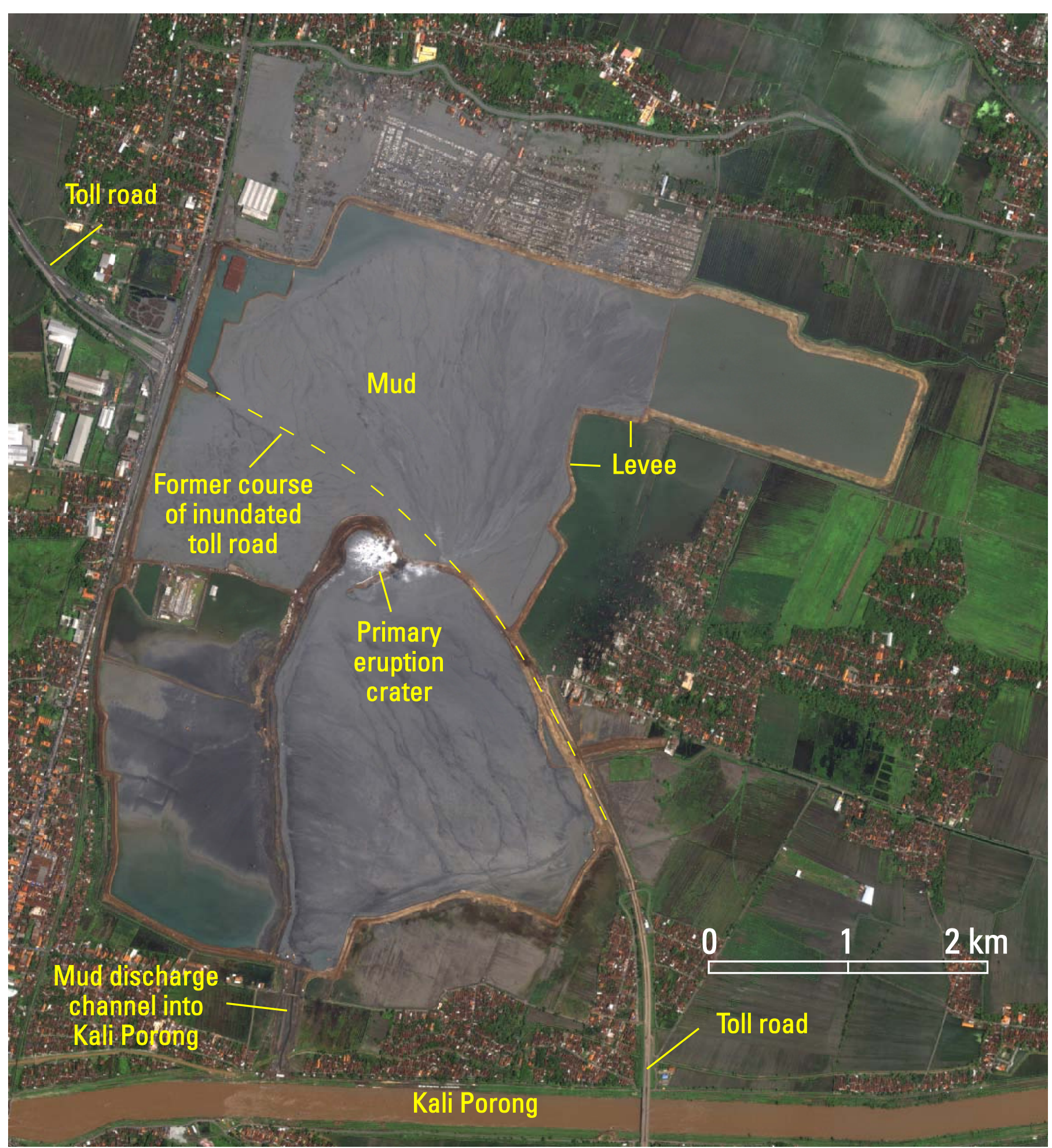

Figure 2. January 5, 2008 Ikonos satellite image of the LUSI mud volcano and surrounding areas inundated by the mud. Ikonos satellite imagery (C) (CRISP) 2008, http://www.crisp.nus.edu.sg, accessed June, 2008. 


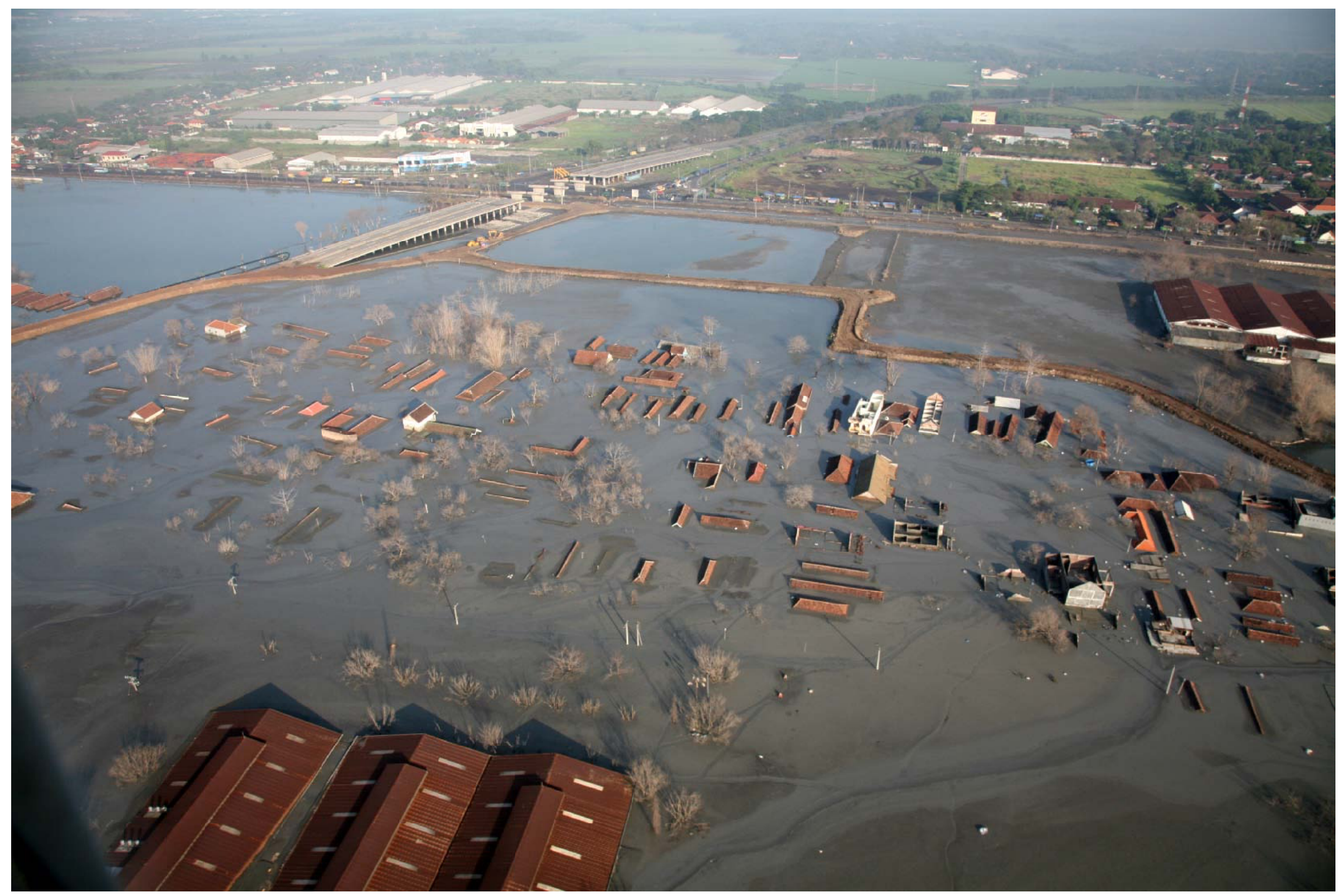

Figure 3. Oblique aerial photograph (early June, 2007) looking west over a portion of the area inundated by the LUSI mud. A bridge on the former toll road is visible in the upper left of the photograph. Comparison of this photograph with the January 5, 2008, satellite image in figure 2 shows that all of the buildings in the foreground have since disappeared, likely buried completely by mud. Photograph by Handoko Wibowo. 

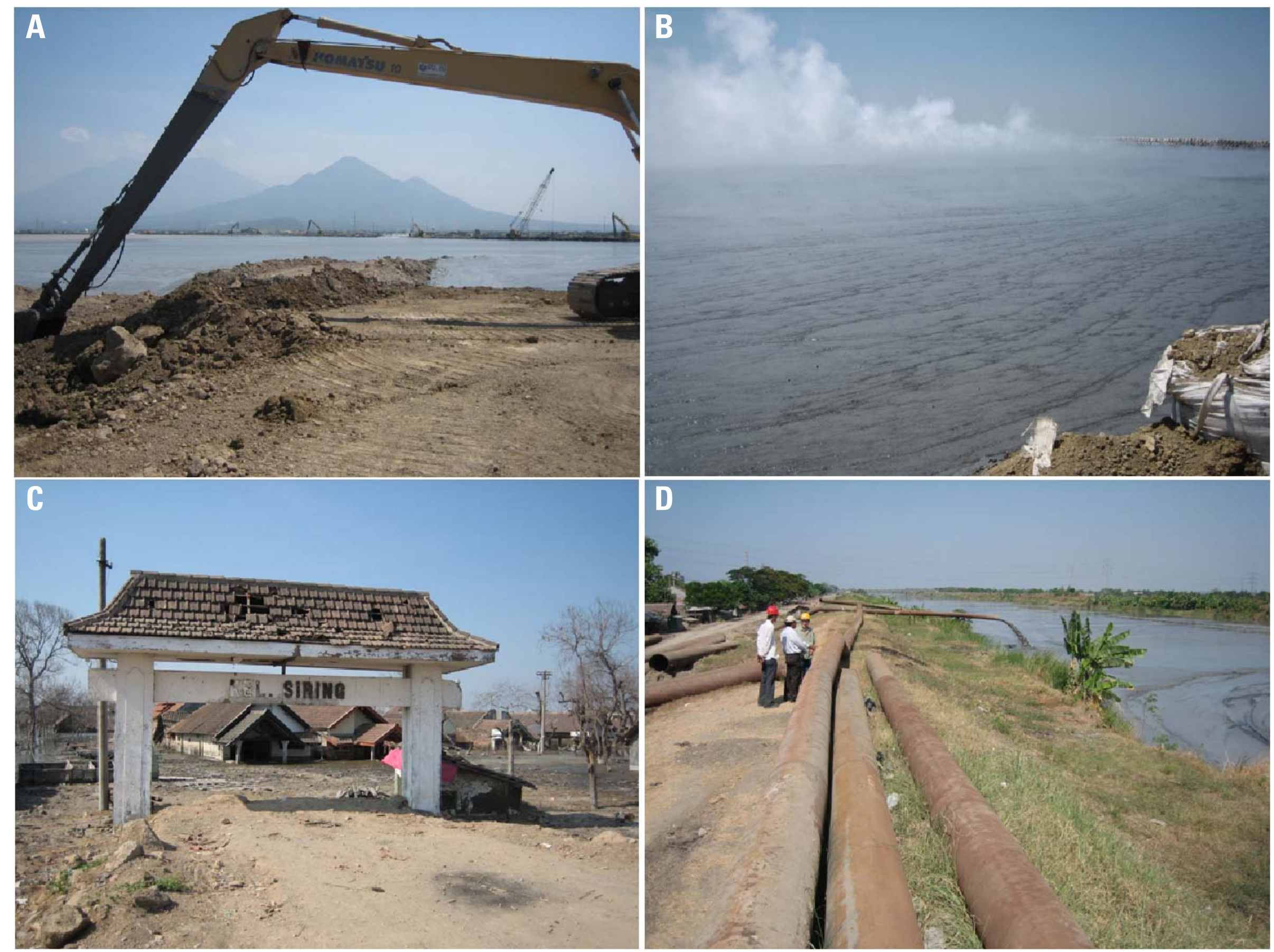

Figure 4. Photographs of the LUSI eruption area, taken by Thomas Casadevall on September 22, 2007. A. View looking southwest of backhoe managing mud from a levee closest to the central eruption crater. Backhoes and a crane can also be seen on the levee in the distance. B. Steam emanates from the central eruption crater. The ripples in the highly liquid mud result from pulsations in the eruption. C. View of a village after it was abandoned due to the mud deposits. D. View of mud being discharged into the Kali Porong. 


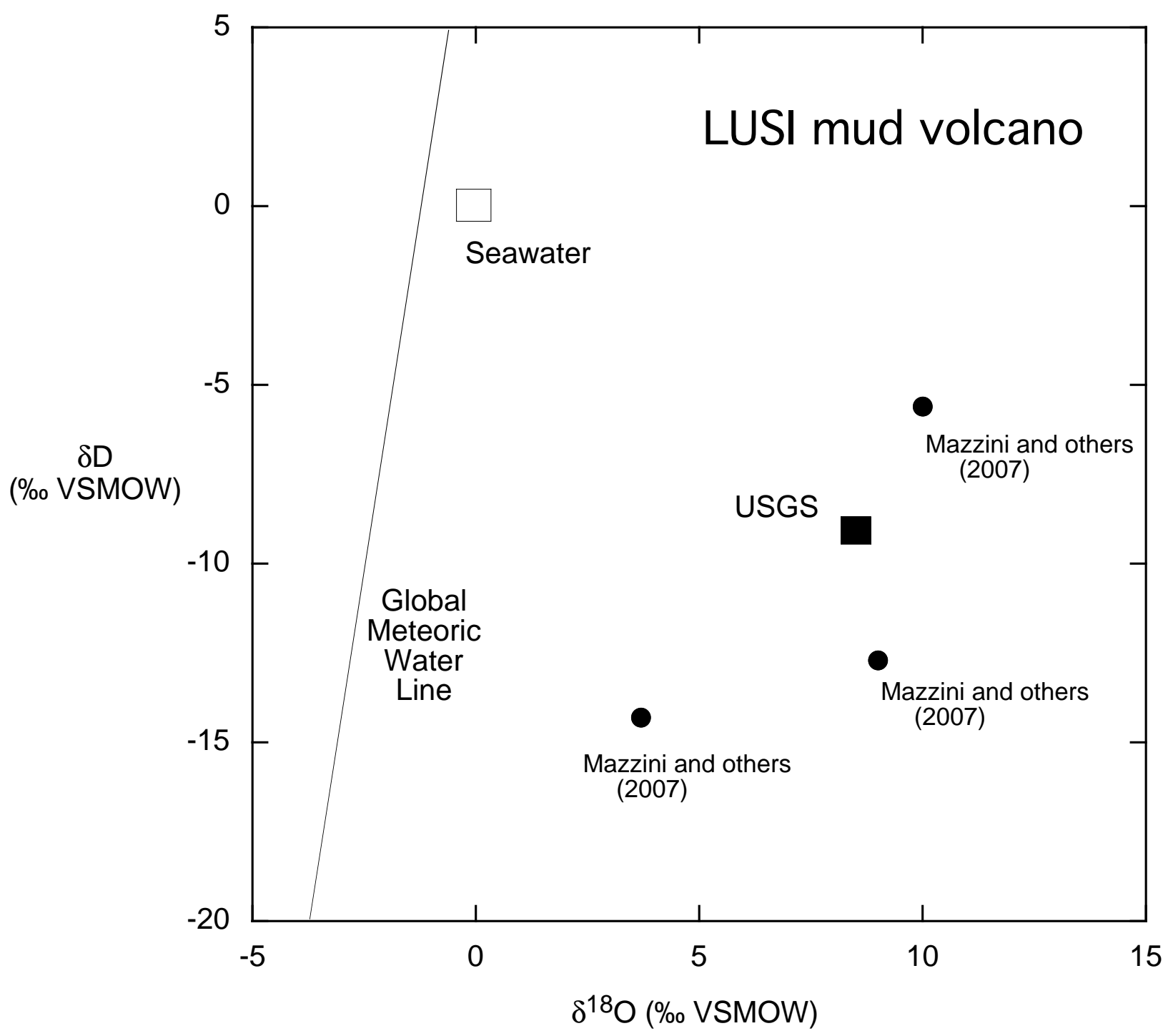

Figure 5. Plot showing hydrogen $(\delta D)$ and oxygen $\left(\delta^{18} 0\right)$ isotopic composition of water separated from LUSI mud sample, compared to compositions obtained by Mazzini and others (2007), as well as seawater and global meteoric water. \%o - parts per thousand. 


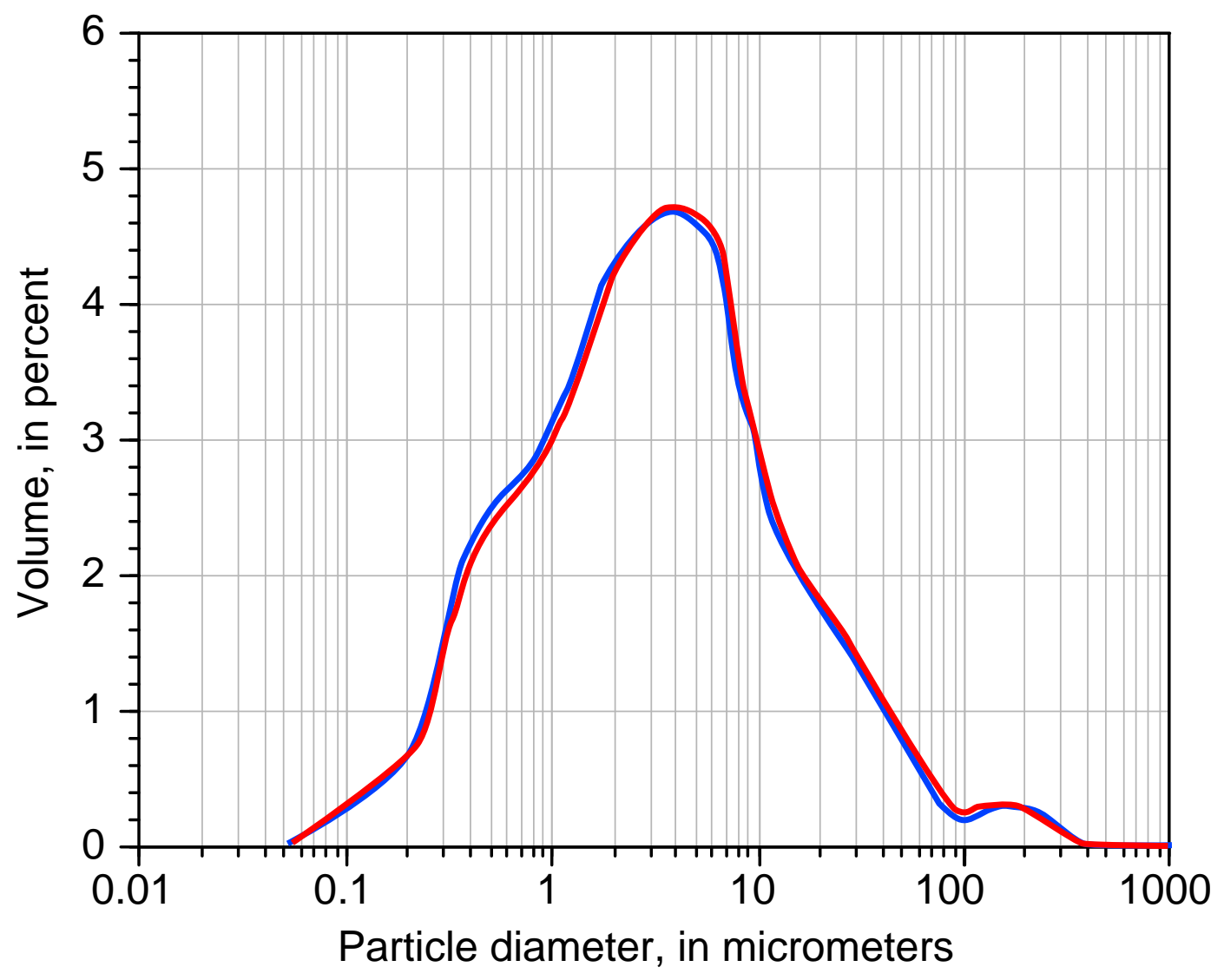

Figure 6. Plot showing particle size distribution of two replicate splits of the LUSI mud sample. 


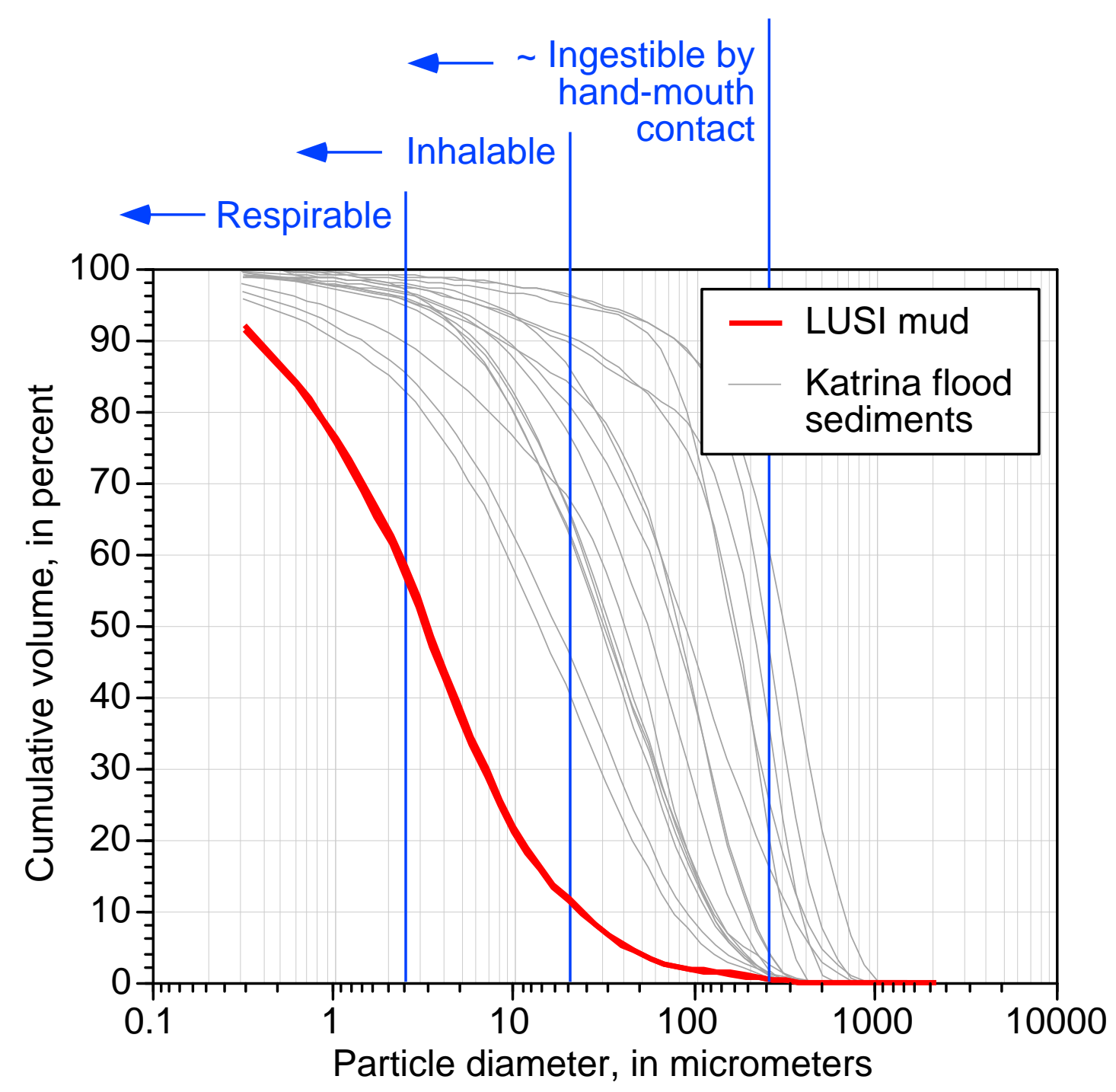

Figure 7. Plot showing particle-size distribution (as cumulative volume percent) of LUSI mud samples compared to those of Hurricane Katrina flood sediments (Plumlee and others, 2007a). Approximate particle-size cutoffs for incidental ingestibility (less than $250 \mu \mathrm{m}$ ), inhalability through nasal breathing (less than $10 \mu \mathrm{m}$ ), and respirability through nasal breathing (less than $2.5 \mu \mathrm{m}$ ) are from sources listed in Plumlee and others (2006). Oral breathing, such as during exercise or very dusty conditions, results in the shift of inhalable and respirable particles to somewhat coarser particle sizes. 


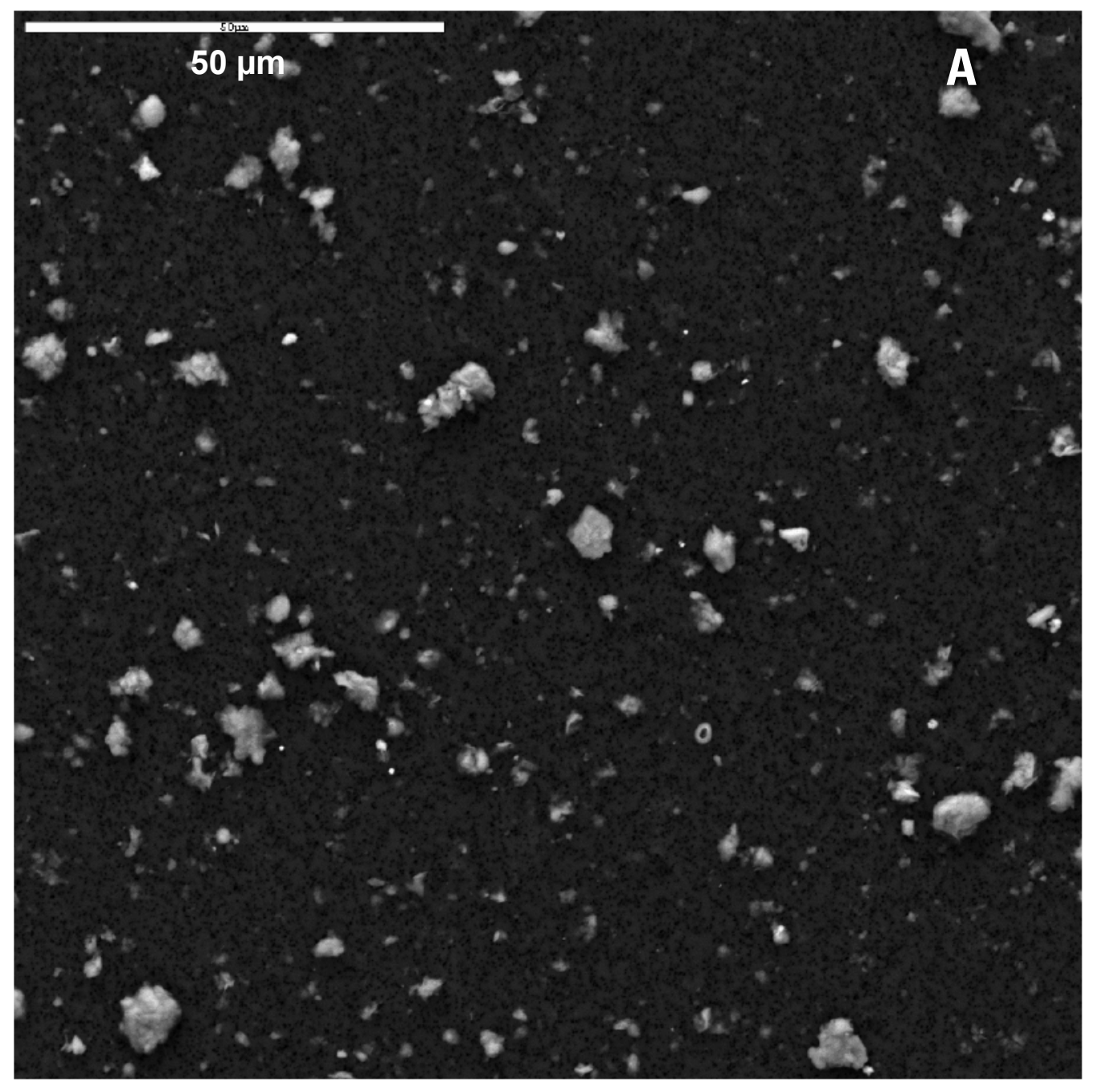

Figure 8. SEM photomicrographs of the LUSI mud sample. The mud was suspended in isopropanol to declump particles, and then the particles were collected by filtering the water suspension through filter paper. Note scale bars vary between A-C. A. Typical view of many particles. B. Typical smectite clay particle. C. Aggregate of many small pyrite (iron disulfide) crystals.

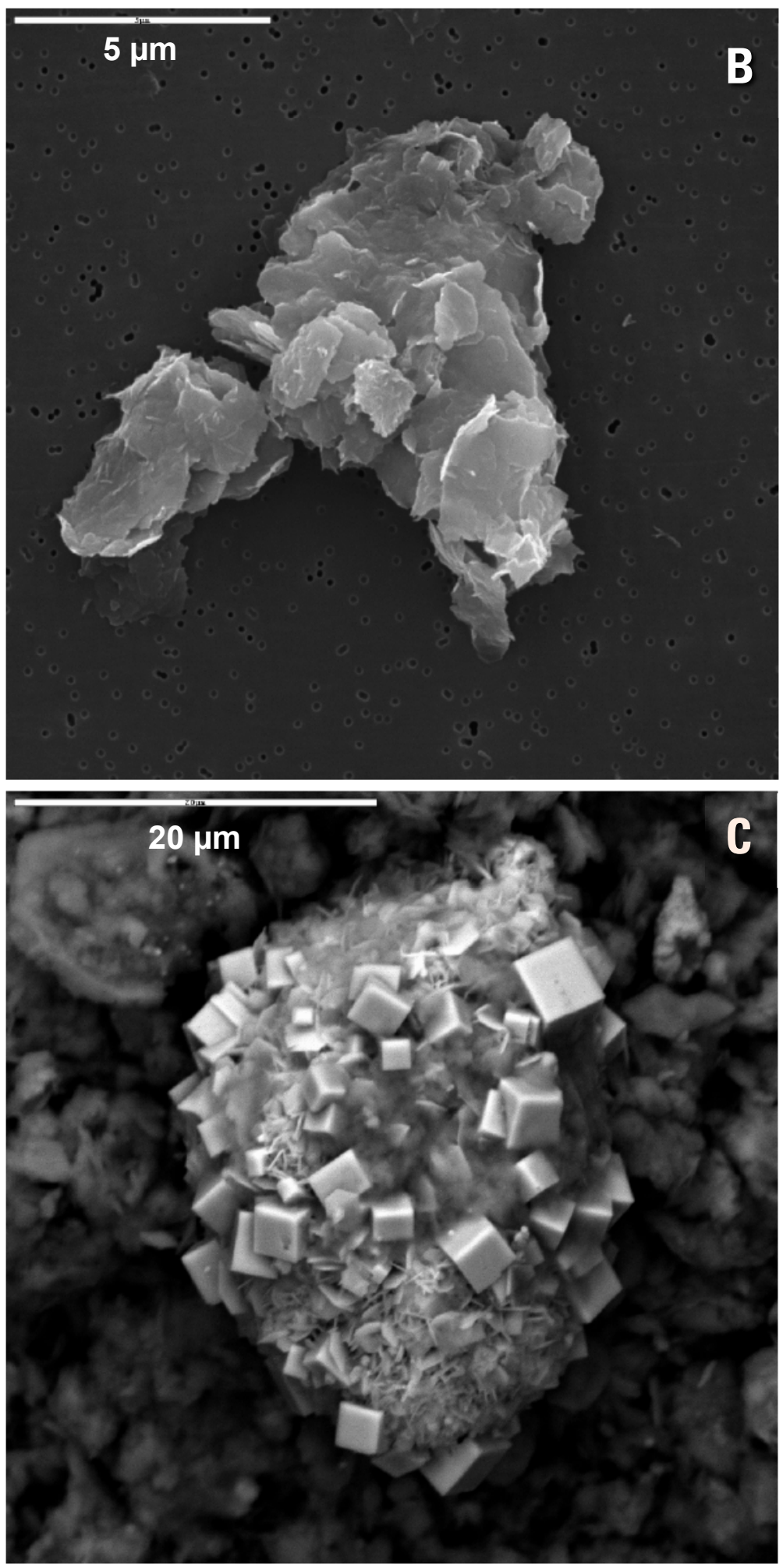

